\title{
Review Article \\ Cell Therapies in Cardiomyopathy: Current Status of Clinical Trials
}

\author{
Ming Hao, ${ }^{1,2}$ Richard Wang, ${ }^{1,2}$ and Wen Wang ${ }^{1,2}$ \\ ${ }^{1}$ Cellular Biomedicine Group, 333 Guiping Road, Shanghai 200233, China \\ ${ }^{2}$ Cellular Biomedicine Group, 19925 Stevens Creek Blvd, Suite 100, Cupertino, CA 95014, USA \\ Correspondence should be addressed to Wen Wang; maxwell.wang@cellbiomedgroup.com
}

Received 22 September 2016; Revised 6 December 2016; Accepted 8 December 2016; Published 17 January 2017

Academic Editor: Alain Chapel

Copyright ( 2017 Ming Hao et al. This is an open access article distributed under the Creative Commons Attribution License, which permits unrestricted use, distribution, and reproduction in any medium, provided the original work is properly cited.

\begin{abstract}
Because the human heart has limited potential for regeneration, the loss of cardiomyocytes during cardiac myopathy and ischaemic injury can result in heart failure and death. Stem cell therapy has emerged as a promising strategy for the treatment of dead myocardium, directly or indirectly, and seems to offer functional benefits to patients. The ideal candidate donor cell for myocardial reconstitution is a stem-like cell that can be easily obtained, has a robust proliferation capacity and a low risk of tumour formation and immune rejection, differentiates into functionally normal cardiomyocytes, and is suitable for minimally invasive clinical transplantation. The ultimate goal of cardiac repair is to regenerate functionally viable myocardium after myocardial infarction (MI) to prevent or heal heart failure. This review provides a comprehensive overview of treatment with stem-like cells in preclinical and clinical studies to assess the feasibility and efficacy of this novel therapeutic strategy in ischaemic cardiomyopathy.
\end{abstract}

\section{Introduction}

Ischaemic cardiomyopathy, which mainly results from the blockage of multiple coronary arteries, is the most common cause of early death in adults worldwide [1]. A myocardial infarction (MI) can kill approximately $25 \%$ of cardiomyocytes in only a few hours [2]. However, the adult human heart has limited potential for regeneration to repair the injury caused by MI. Over the past two decades, cardiac transplantation has been the only available cure for people who develop advanced heart failure [3].

Cardiac homeostasis has traditionally been considered to be static in the adult mammalian heart. This might seem perplexing because the heart is one of the least regenerative organs, and it possesses a relatively constant number of myocytes that are as old as the individual [4]. Even under the most ideal circumstances, when all therapeutic interventions are applied to preserve the remaining myocytes from death, a moderate rate of cellular apoptosis leads to the erosion of the myocardium over time. In this case, the onset of heart failure in the elderly appears to be inevitable.
Currently, remarkable progress has been made to demonstrate the presence of cycling cardiomyocytes in humans [5-7]. Radiocarbon birth dating has suggested that turnover rate in the endogenous adult human heart is approximately $1 \%$ per year, with approximately $45 \%$ of cardiomyocytes predicted to be renewed after birth [8]. Unfortunately, the injury from an acute MI cannot be reversed by resident cardiomyocyte proliferation during normal aging. Pulse-chase labelling has suggested that cardiac stem/precursor cells contribute to cardiomyocytes replenishment and regeneration after injury [9]. Therefore, the existence of cardiac stemlike cells promises a tantalizing approach to the treatment of ischaemic cardiomyopathy.

The ultimate goal of cardiac repair is to regenerate functionally viable myocardium after MI to prevent or heal heart failure. Conventional surgical interventions, such as coronary artery bypass graft (CABG) or percutaneous coronary intervention (PCI), are only able to restore heart function to a minor degree, with an improvement in the left ventricular ejection fraction (LVEF) of only approximately $3-4 \%$ [10]. Stem cell therapy has emerged as a promising 
strategy for the treatment of dead myocardium, directly or indirectly, and seems to offer functional benefits to patients [11].

Recently, a substantial number of clinical trials have proven that stem cell therapy is safe [12]. Infusion of bone marrow-derived stem cells (BMCs) represents the greatest number of clinical studies for MI. The overall efficacy for BMCs from meta-analysis on multiple published data has been inconsistent but relatively modest, with an improvement in LVEF of approximately 3-4\% [11]. The majority of BMCs data for therapy, however, is less than ideal due to the limited component of active undifferentiated stem cells existing in bone marrow from early studies [13]. Many different types of stem cell with greater potential for cardiomyocyte regeneration, such as mesenchymal stem cells, cardiac stem cells, cardiosphere-derived cells, embryonic stem cells, and induced pluripotent stem cells, have been investigated in preclinical studies or clinical trials, which may help to improve the efficacy of cell therapies in cardiomyopathy [14]. The discrepancies among the multiple clinical studies may result from the various types of stem cells utilized in the studies as well as their different isolation and delivery procedures [15]. The beneficial outcomes from cell therapy are associated with paracrine effects, rather than direct regeneration of new tissue [5]. Therefore, large phase III clinical trials will be needed to confirm the salubrious effect of stem cell therapies in MI over placebo control. This review provides a comprehensive overview of treatment with stem-like cells in preclinical and clinical studies to assess the feasibility and efficacy of this novel therapeutic strategy in ischaemic cardiomyopathy.

\section{Types of Stem Cells for Cardiac Cell Therapy}

2.1. Skeletal Myoblasts. Skeletal myoblasts (SKMs) are precursors of satellite cells, which remain in a quiescent state under the basal membrane of muscle fibres [29]. Autologous transplantation of SKMs is conceptually alluring for heart regeneration because SKMs are easily procured during muscle biopsies, because they are highly proliferative after muscle injury, and especially because they are resistant to ischaemia and hypoxia [30]. In June 2000, intramyocardial administration of autologous SKMs derived from the thigh muscle into a patient with severe ischaemic heart failure during CABG established the first use of cell therapy in MI [31]. Several preclinical trials for the use of SKMs to promote cardiac repair in both small and large animal models demonstrated increased LVEF and resulted in a decrease of left ventricular $(\mathrm{LV})$ remodelling without significant formation of new myocardial fibrosis [32-34].

SKMs specifically express myogenic transcription factors including MyoD, Myf5, and PAX7 [35]. Coculture of SKMs and neonatal cardiac myocytes in intercalated discs induced transdifferentiation into cardiomyocytes that expressed the cardiac-specific markers GATA4 and Nkx2.5 together with $\mathrm{N}$-cadherin and connexin $43[36,37]$. Despite the exciting finding that approximately $10 \%$ of the SKMs contracted in synchrony with adjacent cardiomyocytes in vitro, no studies have documented functional coupling of SKMs with the myocardium in vivo [38].

In contrast, SKMs remain skeletal myocytes in the heart and do not differentiate into cardiomyocytes, and infused SKMs fail to contract synchronously with the native myocardium, which results in a high risk of arrhythmias [39]. To date, the largest randomized, placebo-controlled, phase II SKM trial (the MAGIC trial) demonstrated that there was no significant improvement in regional or global LV function after SKM implantation and was discontinued prematurely [40]. Furthermore, the high number of adverse cardiac events secondary to myoblast injections decreased the further application of this treatment due to the availability of other types of stem cells [41].

2.2. Bone Marrow-Derived Stem Cells. In studies of sexmismatched heart transplantations in humans, the Y chromosomes from the host cells were identified to colonize and differentiate in the implanted heart, which indicated the existence of mobile stem-like cells [42]. Under physiological conditions, there are bone marrow-derived stem cells (BMCs) in circulation. Therefore, the discovery of an additional origin of regenerated cardiomyocytes by fate-mapping implies that circulating BMCs continuously contribute to myocytes renewal in humans by means of cell fusion and transdifferentiation after injury $[16,43]$. Sceptics, however, have questioned whether in vivo BMCs can meaningfully differentiate into all three main types of cardiac cells, which include myocytes, smooth muscle, and endothelial cells [44].

BMCs contain several different cell populations including haematopoietic stem cells (HSCs) [45, 46], mesenchymal stem cells (MSCs) [47-49], and endothelial progenitor cells (EPCs) [50, 51]. Therefore, the plasticity of BMCs to proliferate, migrate, and also differentiate into multilineage cell types may arise from the mixture of stem-like cells [52]. HSCs, for example, are defined as a rare population of cells that express CD31, CD34, CD45, CD133, and kinase insert domain receptor (KDR) and are believed to be able to derive all blood lineages and possibly transdifferentiate into cardiomyocytes [53].

Comparatively, a large number of unfractionated autologous cells, in terms of bone marrow mononuclear cells (BMMNCs), are relatively easy to obtain from the pelvic bones of patients [54]. In fact, clinical application could therefore be expedited with very limited convincing preclinical evidence. Only 4 months after the pioneer study of BMC-derived myocardial regeneration in mice [55], the first clinical treatment of a 46-year-old patient with autologous unfractionated BMMNCs for acute MI exhibited significant salubrious effects [56]. However, the outcomes from the initial trials of human myocardial therapy with BMMNCs were mild and controversial [55, 57-59].

The TOPCARE-AMI trial was one of the first randomized clinical trials of BMMNC therapy. Patients who were treated with intracoronary BMMNCs showed an approximately $11 \%$ improvement of LVEF at the five-year follow-up study [60]. The long-term beneficial outcomes from the BALANCE 
study has also proved that treatment with BMMNCs can increase LVEF to $10 \%$, decrease infarction size, and improve quality of life [46]. Conversely, in the BOOST trial, a single intracoronary transfer of unfractionated BMMNCs in patients with acute AMI provided only short-term benefits (approximately 7\% improvement in LVEF), which lasted no more than 6 months [61]. Similarly, the ASTAMI trial observed no effect on global LV function after intracoronary injection of autologous BMMNCs during a study follow-up period ranging from 24 hours to 3 years [17, 62-64]. The results from the TIME trial also demonstrated no recovery of global or regional LV performance and excluded the effect of BMMNC injection time at either 3 days or 7 days [65]. The MYSTAR study utilized a combined delivery through both an intramyocardial and intracoronary route and showed a mild improvement in LVEF of approximately 3.5\% [66]. The REGENT trial used a selected population of CD34+ and CXCR4+ progenitor cells derived from autologous BMMNCs to treat patients with MI. LVEF was not improved in either the selected or unselected cell-treated group compared with patients without cell treatment. However, patients with severely damaged LVEF, whose baseline was less than 37\%, displayed a trend in favour of both cell treatments [67]. To further emphasize this point, 191 patients with an LVEF of $35 \%$ or less due to ischaemic cardiomyopathy were enrolled in the STAR-heart trial. After 12 and 60 months, the BMMNCtreated patients exhibited a statistically significant improvement in LV performance compared with the baseline from the control group, which suggests that cell therapy can affect mortality in patients with chronic heart failure [68]. In other phase II/III trials, a statistically significant but modest and probably not clinically relevant enhancement in LVEF was observed in the REPAIR-AMI study [62]. In addition, no significant improvement in LV function was demonstrated at 4 months in the SWISS-AMI study [69]. To date, over 3000 patients have been treated with bone marrow-derived cells in numerous clinical trials all over the world [70]. Among these studies, a meta-analysis that included 2625 patients enrolled from 50 publications demonstrated that patients treated with BMMNCs showed a relatively moderate refinement in LVEF ( 3.96\%) and smaller infarct size ( - $4.03 \%)$, LV end-systolic volume $(\sim-8.91 \mathrm{~mL})$, and LV end-diastolic volume $(\sim-5.23 \mathrm{~mL})$ [71]. Although the clinical significance of these studies needs to be further evaluated, the mortality, recurrence of MI, and rehospitalization for heart failure were significantly lower in the BMMNC-treated patients than in the control subjects. These favourable findings have catalysed the demand for additional large-scale trials $[71,72]$.

The current use of unfractionated BMMNCs is limited because the vast majority of isolated BMMNCs contain differentiated haematopoietic cells and very few stem cells. Only approximately $2-4 \%$ of HSCs and $0.01 \%$ of MSCs in BMMNCs can effectively be utilized for stem cell therapy [70]. In addition, the discrepancies in the results of the different trials may be partially ascribed to variations in the variables in each trial, such as the number of cells injected, the cell preparations, the delivery procedures, and even the baseline extent of LV dysfunction and geometry of the patients. Therefore, a good manufacturing practice (GMP) process is indispensable to warrant the production of a quality-controlled cell product and prevent contaminations of the end product [73]. With regard to safety, autologous BMCs are still the most frequently used cell type for the treatment of acute MI because among all the clinical trials that have been conducted there have been no observations of carcinogenesis, arrhythmias, or any other adverse effects [74].

2.3. Bone Marrow-Derived Mesenchymal Stem Cells. Bone marrow-derived mesenchymal stem cells (MSCs) are capable of differentiating into all the cells of mesodermal lineage, including osteogenic, chondrogenic, and adipogenic cells [75]. MSCs can be characterized primarily as $\mathrm{CD} 105^{+} \mathrm{CD} 90^{+}$ cells, which will also express CD17, CD29, CD44, CD73, CD106, CD124, and CD166. Their surface antigens are absent of the haematopoietic markers CD14, CD31, CD34, CD45, and CD133. The aforementioned rare population of MSCs in bone marrow can be isolated by plastic adherence and subsequently cultured in vitro [13]. Intriguingly, MSCs lack major histocompatibility complex class II (MHC II) antigens and therefore can evade immune surveillance, which renders allogeneic applications plausible [76]. Under specific microenvironmental stimuli, MSCs can be induced to transdifferentiate into skeletal muscle and cardiac muscle and form functional cardiomyocytes in vivo [49]. In general, the manual preparation of autologous BMMNCs takes at least 4 hours [73]. Compared with autologous therapy, allogeneic human bone marrow-derived MSCs may provide an alternative off-the-shelf product to resolve the logistic, economic, and timing restrictions.

In preclinical study, human bone marrow-derived MSCs reduced myocardial infarctions and increased cardiac function and angiogenesis via intramyocardial transplantation in rat models of ischaemic cardiomyopathy [77-79].

Clinically, the safety and efficacy of the administration of proprietary allogeneic human MSCs (Prochymal) in patients with MI have been evaluated since 2005. All MSCs were isolated and expanded from a single donor and intravenously injected into the infarcted artery. LVEF was increased by approximately $6.7 \%$ over baseline at 6 months [80]. The intramyocardial implantation of autologous MSCs was studied in the PROMETHEUS trial. Six patients who were treated with the MSCs exhibited up to a 9.5\% improvement in LVEF and a $47.5 \%$ reduction in scar mass [81]. To compare the safety and efficacy between autologous and allogeneic MSC therapies for ischaemic cardiomyopathy, a phase I/II randomized comparison (the POSEIDON-pilot trial) demonstrated relatively equal clinical improvements in terms of functional status and quality of life from both therapies. More importantly, the POSEIDON-pilot trial highlighted the potential of an inverse dose response, in which the clinical endpoints from a 20 million cells' injectant showed greater improvement and longer sustainability than injectant from 200 million cells, which suggests the importance of dosing thresholds in future clinical study design [82]. Therefore, a phase II study (the TRIDENT trial) is in progress to 
further estimate the dosage [83]. In addition to bone marrowderived cells, transplantation of MSCs derived from the umbilical cord matrix was investigated in the WJ-MSCAMI study. During an 18-month follow-up, global LVEF was significantly improved by approximately 5\% compared with the placebo group, which suggests that the umbilical cord matrix is an alternative source for MSC treatment [84]. Due to a lack of patient participants and placebocontrolled studies among the early studies [80, 82], a recent report from a phase II, randomized, open-label and placebocontrolled study (the SEED-MSC trial) indicated a moderate $(\sim 5.9 \%)$ enhancement of LVEF from patients treated with autologous MSCs once compared with the placebo group [85]. In addition, there are several ongoing phase II/III trials that assess the efficacy of both autologous and allogeneic MSC therapy in patients with ischaemic cardiomyopathy [86, 87]. Analogous to BMC treatment, MSC therapy also displayed a feasible safety profile, including no ventricular arrhythmias or immunological side effects.

2.4. Adipose-Derived Mesenchymal Stem Cells. The reasonable supply of other noncardiac cell types promises an alternative candidate for regenerative therapeutic strategies for the treatment of ischaemic heart failure, including adiposederived stem cells (ADSCs) [88]. ADSCs can be harvested from the adipose tissue of patients with minimal invasiveness and expanded in vitro more rapidly than bone marrowderived MSCs [89]. As mentioned above, ADSCs have a similar origin as MSCs, which lack MHC class II antigens to prevent the rejection from engraftment into host tissues [90]. More importantly, ADSCs are able to differentiate into mesodermal lineages, cardiomyocytes [91], and endothelial cells [92] upon induction. ADSCs share a common expression profile as $\mathrm{CD}_{105^{+}} \mathrm{CD}^{+} 0^{+}$cells and have a CD49d $\mathrm{d}^{+} \mathrm{CD} 106^{-}$ signature for discrimination [93].

In animal studies, the transplantation of ADSCs resulted in a significant improvement in LVEF and angiogenesis and a significant reduction in infarct area compared with BMMNCs [94]. Furthermore, cardiac functions were also enhanced in the infarcted rat hearts after ADSC engraftment, whereas the secretion of cardiac protective soluble factors was also proposed to induce cardiac function [95].

Several clinical trials were completed recently to explore the safety and feasibility of ADSCs in the treatment of patients with acute MI, such as the APOLLO trial [96], the CSCC_ASC trial [97], and the PRESIE trial [98]. Among these trials, the PRESIE study suggested that autologous injection of ADSCs did not mitigate scar size or increase LVEF but stabilized the scar size in patients with advanced ischaemic heart disease [98]. The preliminary data from the PRESIE study elicited the safety of ADSC treatment; however, additional results are expected from other trials.

2.5. Cardiac Stem Cells. Retrospectively, circulating marrow stem-like cells may home to the myocardium and contribute to cardiac homeostasis [42]. In 2000, Deisher described a population of small, replicating, nonadherent cells, which were isolated from the heart of adult p53-deficient mice, as "cardiac stem cells" because of their multipotency [99]. Subsequently, the existence of resident stem-like cells through cardiac development resulted in substantial progress in autologous stem cell therapy for ischaemic cardiomyopathy. Cardiac stem cells (CSCs), by definition, are self-renewing cells that are able to differentiate into a minimum of three cardiac cell lineages: myocytes, smooth muscle, and endothelial vascular cells [100]. CSCs or putative innate cardiac progenitor cells were isolated from independent groups including, c-kit ${ }^{+}$ cells [101], Sca- $1^{+}$cells [102], Islet- $1^{+}$cells [103], SSEA-1 ${ }^{+}$cells [104], PDGFR $\alpha^{+}$cells [105], side population cells [106], and cardiosphere-derived cells [107]. In clinical studies, however, the physiological roles of those cardiac stem/progenitor cells in regeneration of ischaemic cardiomyopathy have not yet been fully investigated except c-kit ${ }^{+}$cells and cardiospherederived cells [108].

In particular, c-kit ${ }^{+}$cells were characterized by the expression of stem cell antigens c-kit (CD117), Sca-1, and MDR1 and are absent of the haematopoietic surface antigens CD31, CD34, CD45, CD133 [101]. Besides, these c$\mathrm{kit}^{+}$cells were identified to colonize at the yolk sack [109], whereas the ligand of the c-kit receptor (SCF) is expressed in the foetal and neonatal myocardium [110]. These findings emphasize that stem-like cells may reside in the heart after birth. Moreover, when injected into the ischaemic heart in

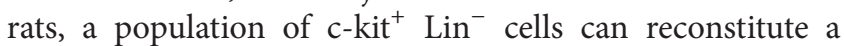
functional myocardium [101]. These cells are negative for blood lineage markers (Lin) and haematopoietic markers (CD34 and CD45), which highlights that the cardiac stemlike cells are in the myocardium long enough to lose their blood cell lineages [101, 111]. Endogenous CSCs have been detected in the extremely low proportion of only $0.01 \%$ of cardiomyocytes [101], which explains the low turnover rate under physiological conditions. However, because CSCs are native to the heart and are specifically restricted for differentiation into cardiac lineages, they represent an ideal cell candidate for heart regenerative therapy after ischaemic insult [54].

A meta-analysis systematically analysed 80 preclinical studies including 1970 animals and verified the consistency of the beneficial effects of CSC therapy on MI. The overall effect of CSC treatment in small animals was an improvement in LVEF by approximately $12 \%$ compared with the placebo groups, whereas an approximately $5 \%$ improvement in LVEF was observed in large animals [112].

The SCIPIO study was the first phase I, randomized, open-label clinical trial to evaluate autologous c-kit ${ }^{+} \mathrm{CSCs}$ in patients with ischaemic MI whose LVEF was lower than $40 \%$. The CSCs were isolated from the right atrial appendage during CABG surgery. Ex vivo expanded $1 \times 10^{6}{\mathrm{c}-\mathrm{kit}^{+}}^{+}$ CSCs were administered to 16 patients through intracoronary infusion approximately 4 months after CABG. Compared with the patients from the control group, cardiac MRI showed an increase in LVEF by approximately $8 \%$ and $12.3 \%$ at 4 months and 12 months after CSC injection, respectively. No evidence of tumour formation was observed after a 1-year follow-up. At the preclinical level, only $4-8 \%$ of transplanted CSCs colonized and persisted in the myocardium 1 year after 
infusion [113]; however, it was speculated that clinically $4-8 \%$ of transplanted CSCs would be insufficient to account for the functional and structural benefits of the CSC treatment in SCIPIO study since specimens of transplanted myocardium were difficult to acquire [114]. It was suspected that the major mechanism for the beneficial effects might be attributable to paracrine factors, which are released by the injected cells to modulate the proliferation of the host cardiac cells [113]. The CONCERT-HF trial is recruiting patients to investigate the safety and efficacy of autologous bone marrow-derived MSCs and c-kit ${ }^{+}$CSCs both alone and in combination for the treatment of ischaemic cardiomyopathy [115].

2.6. Cardiosphere-Derived Cells. Human cardiac stem-like cells can migrate out of in vitro cultured human myocardial biopsies and form spheroids in suspension conditions. Those spherical clusters are termed cardiospheres (CSps) and are capable of self-renewal and are positive for the endothelial marker CD31 and cardiac progenitor cell markers such as c-kit, CD-34, Sca-1, and Nkx2.5 [107]. In fact, CSps are a heterogeneous mixture of cardiac stem cells, differentiating progenitors and differentiated cardiomyocytes, depending on the size of the spheroid and the time in culture. C$\mathrm{kit}^{+}$cells were found to be localized in the centre of the spheroids and are positive for BrdU staining, which suggests the proliferation and differentiation hierarchy of c-kit+ cells in the growth of CSps [107]. Notably, cardiosphere-derived cells (CDCs) are able to differentiate into cardiomyocytes and vascular cells, and only the cells in the centre are maintained in an undifferentiated state, whereas the cells at the surface layer are continuously undergoing differentiation [116]. In addition, cardiac stem-like cells, similar to other types of adult stem cells, sustain their multipotency within an appropriate niche [117]. CDCs can also enhance cardiac function once injected into infarcted rat hearts [107].

CDCs exhibited superior cardiomyogenic differentiation potential, angiogenic formation, and paracrine factor secretion compared with BMMNCs, bone marrow-derived MSCs, and adipose-derived MSCs in mice [118]. Furthermore, a mixture of CDCs also outperformed purified c-kit ${ }^{+}$CSCs in the same study, which suggests that the supporting cells somehow improve the function of the stem-like cells in vivo [118].

These results led to the initiation of several phase I clinical trials involving CSps, including the CADUCEUS [119] and ALCADIA [120] trials, which assessed the feasibility and safety of an intracoronary injection of autologous CSps after a recent infarct. Results from the CADUCEUS study showed an average decreased scar size of $12.3 \%$ at 12 months. Although regional function was improved, no improvement in global function was reported [121]. Safety concerns were raised during the injection of CSps because their size (50-200 $\mu \mathrm{m})$ may potentially cause capillary plugging [122]. Larger studies to evaluate the safe dosage and efficacy of these treatments are in demand.

As with MSCs, CDCs exhibit mesenchymal properties and lack MHC II antigen, which endow the application of allogeneic CDCs [123]. The safety and efficacy between autologous and allogeneic CDCs transplantations to treat ischaemic cardiomyopathy in large animal studies were comparable [124], resulting in at least three ongoing clinical trials, including ALLSTAR, DYNAMIC, and HOPE, for further investigations [125-127].

2.7. Embryonic Stem Cells and Induced Pluripotent Stem Cells. Embryonic stem cells (ESCs) are derived from the inner cell mass of the early embryo in the blastocyst stage. They are self-renewing, clonogenic, and capable of differentiating into any type of cell in the adult, including cardiomyocytes $[128,129]$. It has been proven that ESCs are able to differentiate into all specialized cell types in the heart in vitro, such as atrial-like, ventricular-like, sinus nodal-like, and Purkinje-like cells [130]. The expression of cardiac-specific transcription factors such as GATA4, Nkx2.5, Mef2c, and Irx 4 has been found in human ESC-derived cardiac cells [131]. Moreover, cultured ESC-derived cardiomyocytes beat spontaneously and synchronously under physiological conditions [132]. In a mouse model of myocardial infarction, direct injection of $5 \times 10^{4}$ genetically engineered ESCs improved cardiac function by 4 weeks. From that study, $21 \%$ of the mice formed teratomas after transplantation because of the unlimited differentiation potential of ESCs [133]. Therefore, highly enriched cardiomyocytes derived from murine ESCs, which were produced through the selection of the cardiacspecific promoter NCX1 and constructed with puromycinresistant cells from embryonic bodies, circumvented the issue of teratoma formation [134].

However, embryonic stem cells may not be ideal for clinical application because of their ethical concerns [135], potential genetic instability [133], and the risk of immune rejection [136]. Currently, only one clinical trial is actively recruiting patients to test the use of human embryonic stem cell-derived $\mathrm{CD}^{+} 5^{+}$Isl-1 $1^{+}$progenitors in severe heart failure (the ESCORT study) [137].

Enforcing expression of OCT4, SOX2, KLF4, and c-MYC transcription factors can reprogram terminally differentiated cells to closely resemble embryonic stem cells, which are termed induced pluripotent stem cells (iPSCs) [138]. Functional cardiomyocytes have now been successfully derived from both mouse [139] and human iPSCs [140]. As an alternative source for all cardiogenic cell lines, iPSCs can be derived from individual patients for autologous transplantation to minimize the risk of immune rejection and resolve the ethical issues [138].

The pitfalls of iPSC application include the risk of teratoma formation associated with the pluripotent state, whereas defining reliable methods for inducing highly enriched populations of cardiomyocytes are essential [141143]. Meanwhile, the low efficiency of cardiogenic differentiation, high costs, and time-consuming methods (approximately 4 months) of iPSCs require further investigation [144], which should also explore the generation of cardiomyocytes from somatic cells without transit through a pluripotent state $[145,146]$. Attempts to manufacture clinical grade iPSCs products from blood and skin samples are in progress [147, 148]. 


\section{Clinical Indications and Unresolved Issues}

As mentioned above, the vast majority of completed human clinical trials are difficult to clarify and compare because the delivered cells are either mixed or enriched populations, and the number of implanted cells, delivery methods, and injection time intervals after MI are different (Table 1). Taken together, clinical endpoints from stem cell treatment in MI are feasible and safe; however, their efficacy has been inconsistent but modest, which allows significant room for improvement.

The variable and moderate benefits associated with stem cell treatments were initially ascribed to inefficient cell delivery, with only $10 \%$ (or less) of the cells retained in the heart after 24 hours regardless of the cell type or delivery route [149]. The cells are usually washed out through the coronary venous system or mechanically ejected from the injection site [150]. Repeated administrations of BMCs, MSCs, and CDCs were demonstrated to boost therapeutic benefits for chronic heart failure [151-153]. The following are three routes for delivering stem cells for cardiac therapy: systemic intravenous infusion, intracoronary infusion, and intramyocardial injection. For intravenous infusion, only $0.04 \%$ of the infused cells reach the infarct region, whereas uptake of cells was found in other organs, especially in the lungs [154]. The advantage to intravenous injection is its simplicity and least invasive nature, which allows the option of treatment with repeated cell injections. Its safety and feasibility have been verified in a phase I clinical trial with a 1-year follow-up [80]. And the efficacy for intravenous injection of human MSCs after AMI was conducted under a phase II study [155].

Direct intramyocardial injection through open-chest surgery during CABG offers the most precise and accurate approach for implanting stem cells into the infarcted region of the heart [156]. But the invasive nature of this operation increased the risk of complications and mortality and prolonged the period for recovery. To circumvent the demand of delivery routines for surgically high-risk patients and applications for repeated therapies, percutaneous catheter-based intramyocardial injection has been developed dependent on the arterial access of individual patient, such as transcoronary venous approach [157] and transendocardial approach [58]. In a substudy of the MYSTAR trial, the myocardial perfusion imaging with single photon emission computer tomography (SPECT) unraveled an average increase in tracer uptake of $6.2 \%$ BMCs in intramyocardial area, suggesting a major beneficial effect on those patients exhibiting individual improvement via intramyocardial injection [158].

For the most clinically practiced procedure, intracoronary delivery uses balloon catheters to infuse stem cells into a coronary artery, where blood flow was interrupted by inflating the balloon to homogenously distribute stem cells [159]. There is still substantial loss of injected cells due to extravasated and venous washout [160]. Tracing BMCs labelled with 18 -fluorodeoxyglucose revealed that only $1.3 \%$ to $2.6 \%$ of cells were retained in the infarcted myocardium after intracoronary transplantation [161]. Treatment efficacy was increased through physical retention of the cells with fibrin glue [150] and biomaterial scaffolds $[162,163]$ to boost homing of the stem cells in the host tissue.

Indeed, a remarkable 6700-fold range in cell dosage was nonsystematically investigated through the vast majority of preclinical and clinical studies worldwide [164]. It was suggested that there might be a threshold between the dosage of BMCs and the therapeutic effects [72].

Due to inflammation or anoikis, over $90 \%$ of the successfully retained cells are not able to survive after one week [165], of which less than $1 \%$ of the infused cells can be identified 4 weeks after transplantation [166]. Most stem-like cells die within days or weeks of transplantation into infarcts [167], although discrepancies may also arise from different injection times among or even within each clinical trial or in variations in the techniques for cell isolation, incubation, and expansion. Compared with unfractionated BMMNCs, the preparation and expansion of bone marrow-derived MSCs for therapy require at least 7 days, whereas the endogenous conditions from each patient may be varied [168]. Sufficient time for the selection and expansion of specific progenitor cells and particularly allogeneic off-the-shelf cell products is urgently needed.

The pathological conditions for acute infarction, chronic ischaemia, and chronic heart failure are distinctive in regard to each patient's local vascular, cellular, and chemical microenvironments. Patients who suffer from worse baseline myocardial infarctions seem to benefit the most from cell therapy in several clinical scenarios. In the BOOST study, functional improvement was observed only in cell-treated patients with greater infarcted areas [61]. Similarly, in the REGENT and REPAIR-AMI studies, only patients with lower baseline LVEF showed sustained recovery at a later time point $[67,169]$. These findings indicate that future design of studies for cell therapy should target a sicker patient population [54]. Though enrolment of patients with poorer LVEF may favour their risk-benefit ratio [170], cardiovascular risk factors, such as age, hypertension, diabetes, hyperlipidemia, smoking, obesity, and hyposthenia, all need to be considered in clinical studies. These cardiovascular risk factors were reported to negatively influence the proliferation and function of stem cells, which will indeed compromise the efficacy of autologous cell therapy in pilot studies [171]. For instance, progenitor cells from the elderly showed decreased telomerase activity and increased cellular senescence, suggesting an age-related decline of outcomes from marrow-derived cell treatment [172]. Diabetes not only impairs the number of BMCs but also interferes with the homing signals to prevent vascular integration, leading to reduced benefits from cell therapy $[173,174]$. In BONAMI trial, active smokers showed impairments in cardiac function recovery from BMCs treated group due to mobilization of progenitor cells [175]. It was suggested that LVEF can be profoundly ameliorated by BMCs transplantation combined with CABG and early onset (7-14 days after MI) engraftment [176].

To date, tissue retention of implanted stem-like cells is disappointingly low; however, their salubrious effects can last for years, which suggests indirect paracrine effects that activate endogenous regenerative mechanisms to benefit the infarcted hearts [177]. Despite the extremely low prevalence 


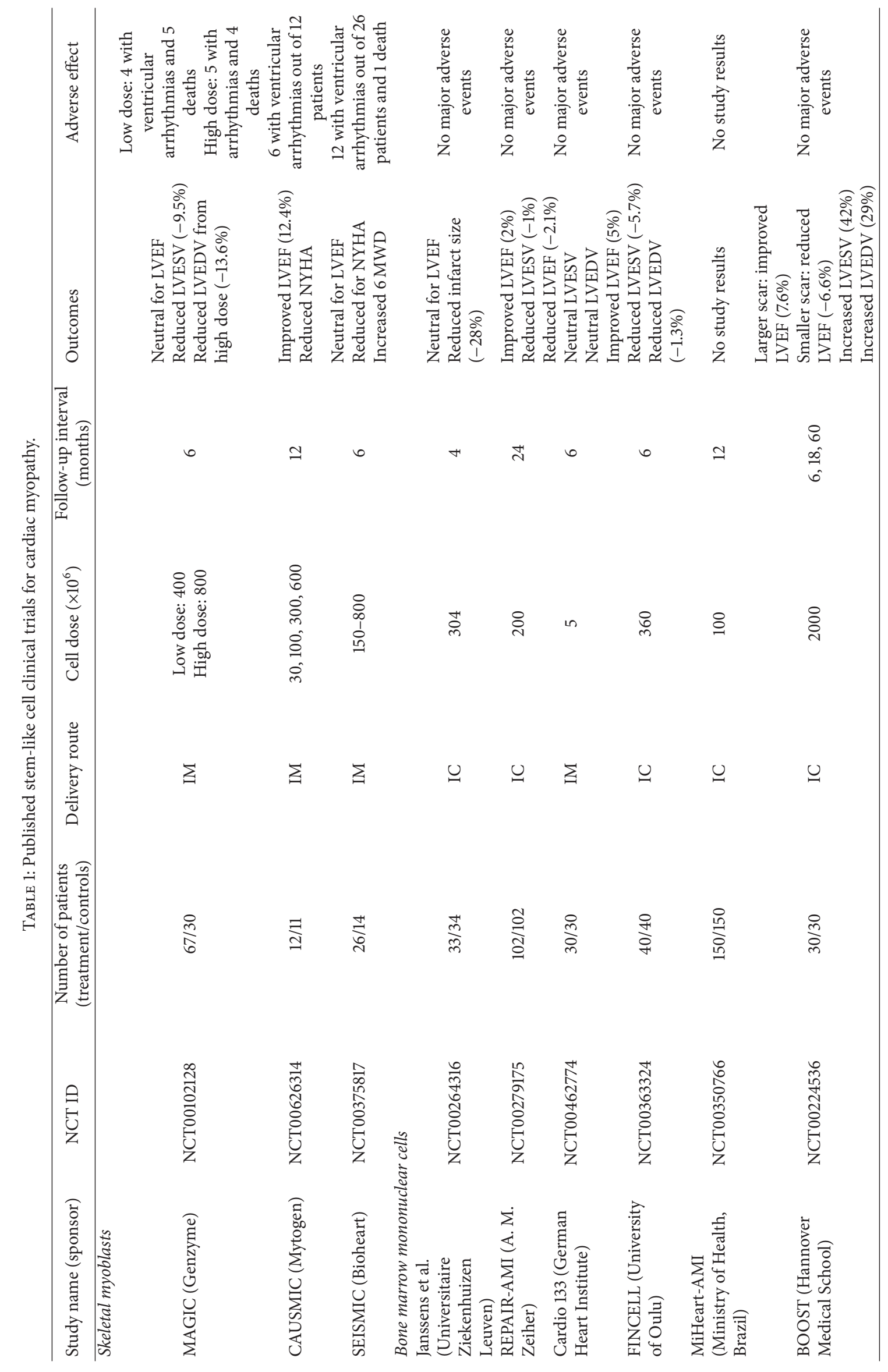




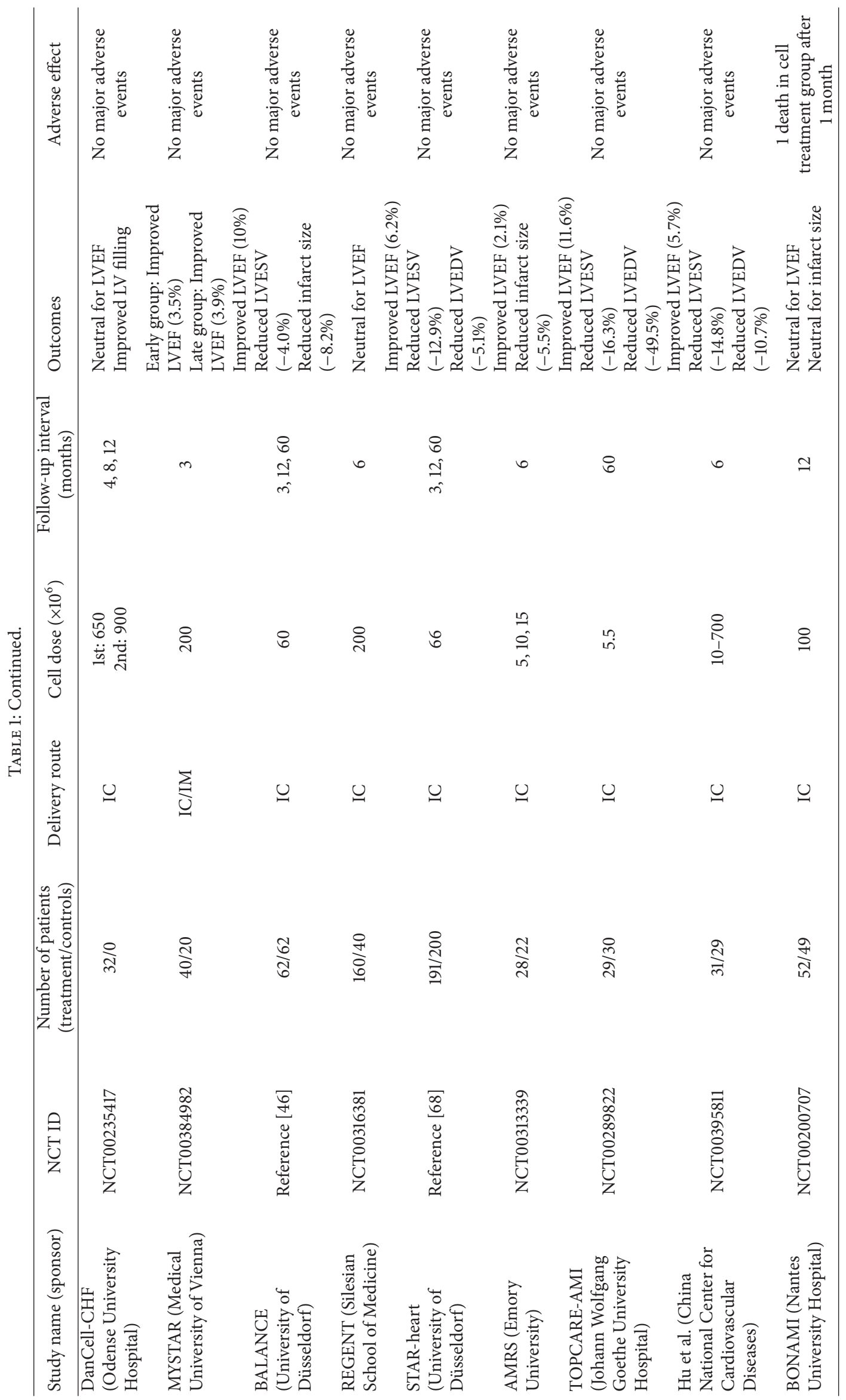




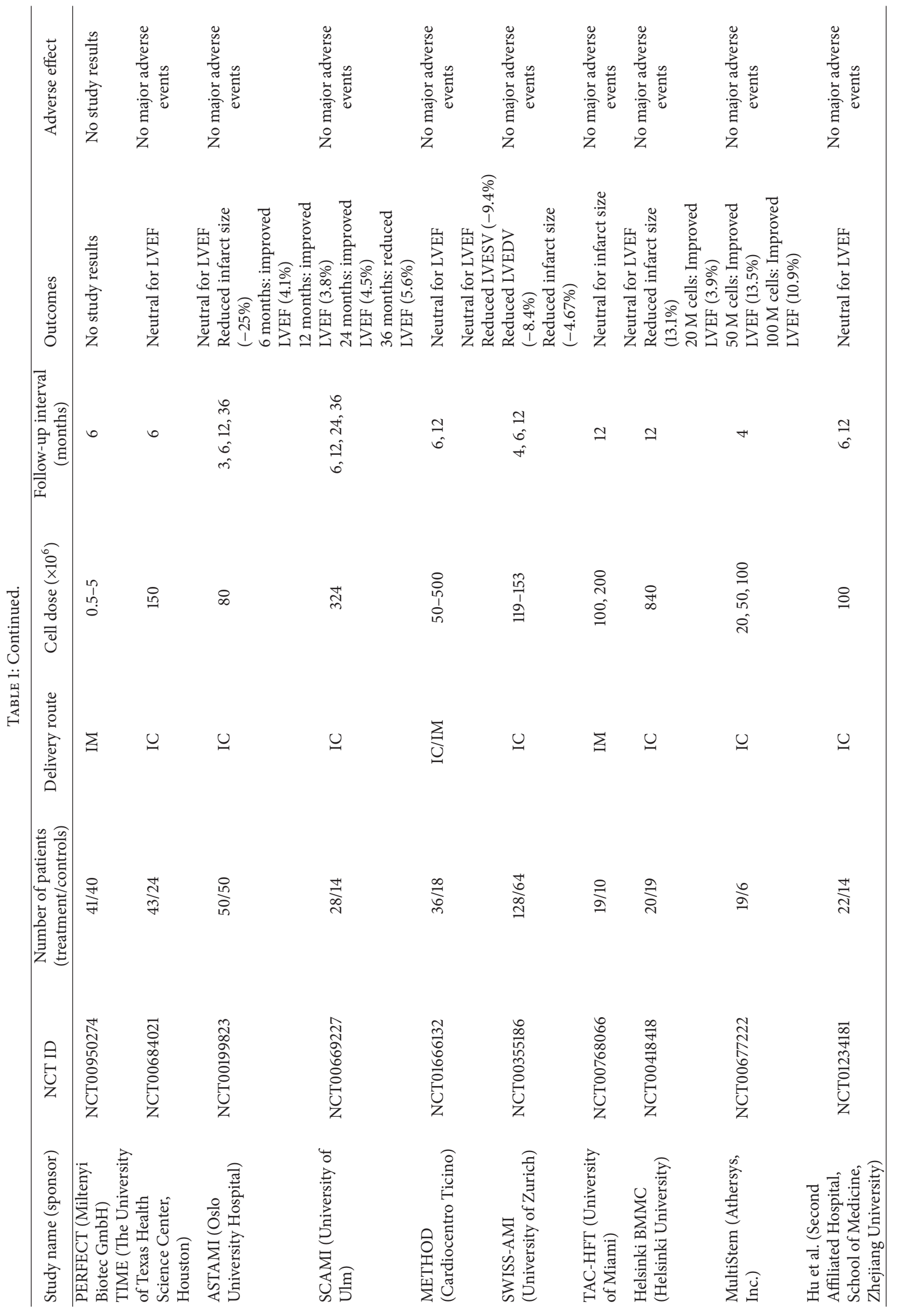




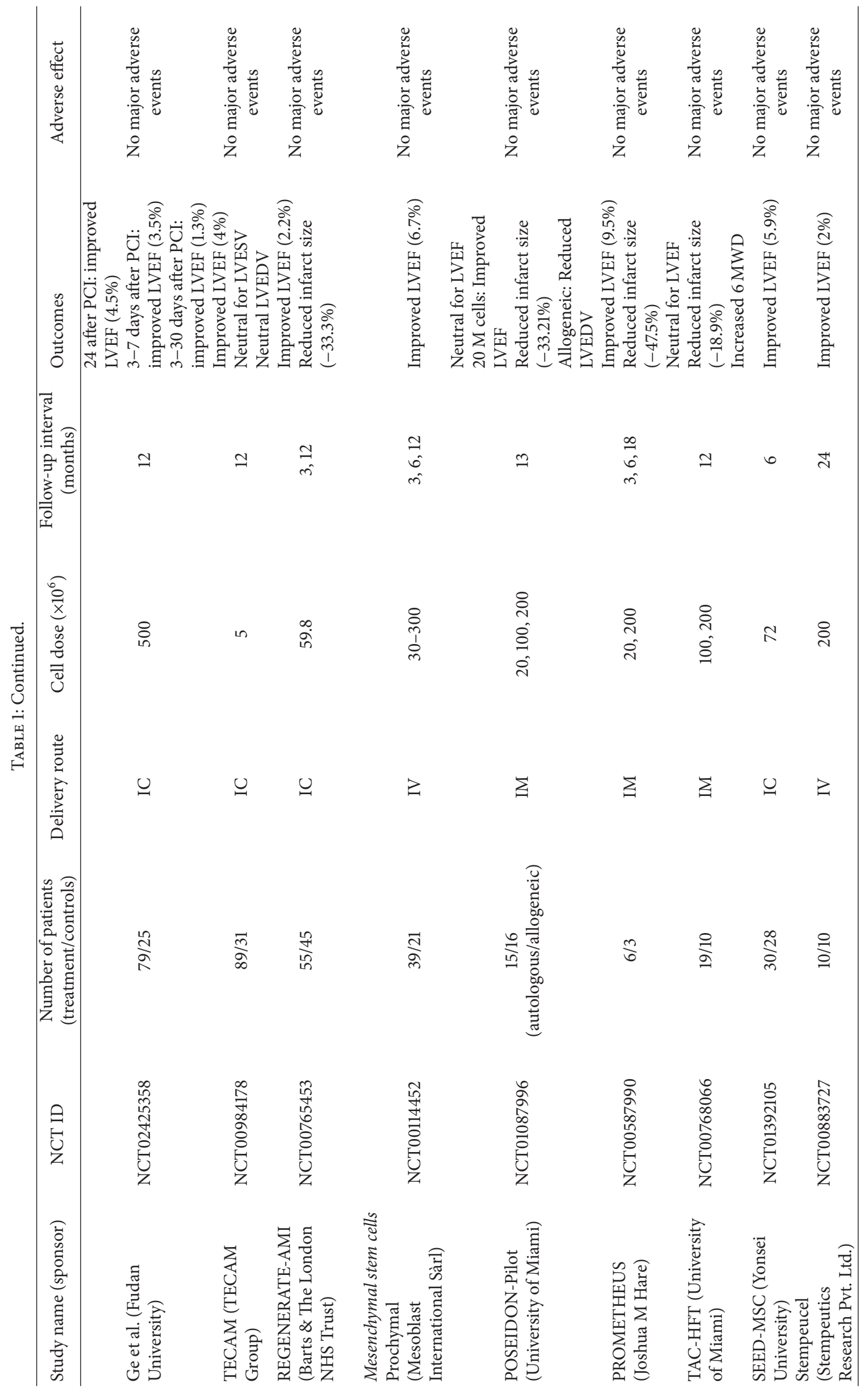




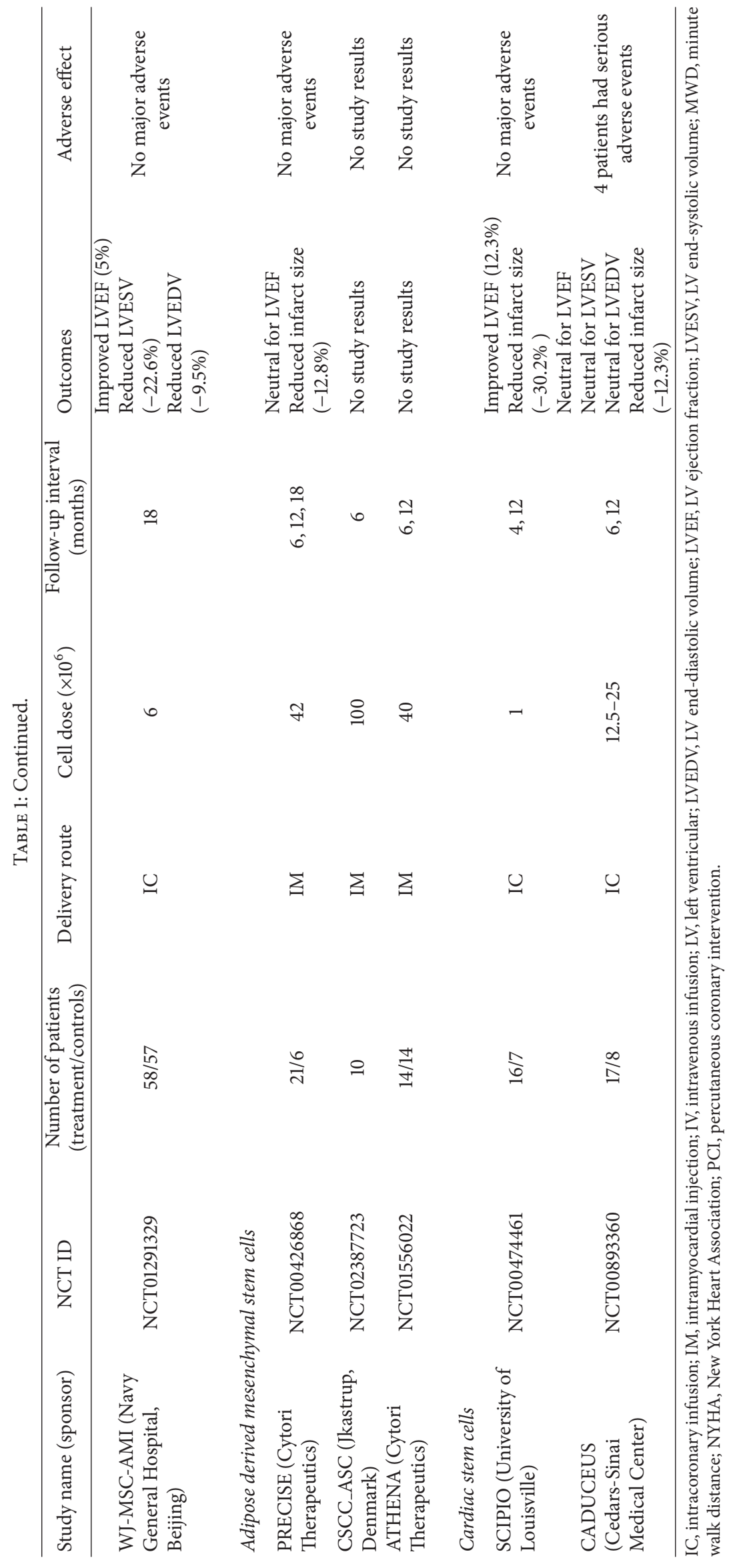


TABLE 2: Putative paracrine factors released by stem-like cells.

\begin{tabular}{|c|c|c|c|}
\hline Putative paracrine factor & Symbol & Proposed function & Reference \\
\hline ABI family member 3 binding protein & ABI3BP & Cell development; tissue remodeling & {$[18]$} \\
\hline Adipocyte complement-related protein & ADIPOQ & $\begin{array}{l}\text { Cell growth; angiogenesis; tissue } \\
\text { remodeling }\end{array}$ & [19] \\
\hline Angiopoietin 1 & AGPT 1 & Angiogenesis & {$[20,21]$} \\
\hline Angiopoietin 2 & AGPT 2 & Angiogenesis & {$[20]$} \\
\hline Agouti-related protein & AgRP & Homeostasis & {$[19]$} \\
\hline Angiogenin & ANG & Angiogenesis; proliferation & {$[18,19]$} \\
\hline Bone morphogenetic protein 2 & BMP2 & Cell development & {$[19,20]$} \\
\hline Bone morphogenetic protein 4 & BMP4 & Cell development; differentiation & {$[20]$} \\
\hline Chemokine ligand 23 & CCL23 & Cytoprotection; cell proliferation & [19] \\
\hline Colony stimulating factor & CSF1 & Cell proliferation; differentiation & {$[20]$} \\
\hline Chemokine ligand 13 & CXCL13 & Inflammation; cell development & [19] \\
\hline Fibrillin 1 & FBN1 & Structural protein; cell signal & {$[19]$} \\
\hline Fibroblast growth factor 1 & FGF1 & Cell proliferation; migration & {$[18-20,22]$} \\
\hline Fibroblast growth factor 2 & FGF2 & Cell proliferation; migration & {$[20]$} \\
\hline Fibroblast growth factor 6 & FGF6 & $\begin{array}{l}\text { Cell proliferation; angiogenesis; } \\
\text { differentiation }\end{array}$ & {$[19]$} \\
\hline Fibroblast growth factor 7 & FGF7 & Cell proliferation & {$[19]$} \\
\hline Hypoxic-induced Akt regulated stem cell factor & HASF & Cytoprotection; cell proliferation & [18] \\
\hline Hepatocyte growth factor & HGF & $\begin{array}{l}\text { Cell migration; angiogenesis; } \\
\text { cytoprotection }\end{array}$ & {$[18,20,22]$} \\
\hline Insulin-like growth factor 1 & IGF1 & Cell growth; proliferation; cytoprotection & {$[18,20,23,24]$} \\
\hline Interleukin 1 & IL1 & Inflammation; cell signal & {$[20]$} \\
\hline Interleukin 2 & IL2 & $\begin{array}{l}\text { Inflammation; cytoprotection; } \\
\text { proliferation; differentiation }\end{array}$ & {$[25]$} \\
\hline Interleukin 5 & IL5 & $\begin{array}{l}\text { Inflammation; cytoprotection; } \\
\text { proliferation; differentiation }\end{array}$ & {$[19]$} \\
\hline Interleukin 6 & IL6 & Inflammation; cell signal & {$[20,22,25]$} \\
\hline Interleukin 8 & IL8 & Inflammation & [25] \\
\hline Interleukin 10 & IL10 & Inflammation; cell signal & [19] \\
\hline Interleukin $12 \mathrm{~B}$ & IL12B & Inflammation; cytoprotection; cell growth & [25] \\
\hline Interleukin 16 & IL16 & Inflammation; proliferation & [25] \\
\hline Inhibin beta $\mathrm{A}$ & INHBA & Cell signal; cell growth & [19] \\
\hline Integrin $\beta 1$ & ITG $\beta 1$ & Cell signal; cell attachment & {$[20]$} \\
\hline MicroRNA 132 & miR-132 & $\begin{array}{l}\text { Inflammation; angiogenesis; cell } \\
\text { development }\end{array}$ & {$[26]$} \\
\hline MicroRNA 146a & miR-146a & Cell growth; proliferation & {$[26,27]$} \\
\hline MicroRNA 210 & miR-210 & Angiogenesis; cytoprotection & {$[26]$} \\
\hline Matrix metalloproteinase 2 & MMP2 & Extracellular matrix degradation & {$[20,28]$} \\
\hline Matrix metalloproteinase 3 & MMP3 & Extracellular matrix degradation & {$[25]$} \\
\hline Matrix metalloproteinase 9 & MMP9 & Extracellular matrix degradation & {$[20,28]$} \\
\hline Matrix metalloproteinase 27 & MMP27 & Extracellular matrix degradation & [19] \\
\hline Nerve growth factor & NGF & Cytoprotection & {$[20]$} \\
\hline Neuregulin & NRG & Angiogenesis; cell proliferation & {$[18]$} \\
\hline Netrin G1 & NTNG1 & Cell development & {$[19]$} \\
\hline Orosomucoid 2 & ORM2 & Inflammation & [19] \\
\hline Platelet-derived growth factor & PDGF & Cell proliferation; angiogenesis & {$[18,20]$} \\
\hline Prostaglandin E2 & PGE2 & Cell development; cell proliferation & {$[18]$} \\
\hline
\end{tabular}


TABLE 2: Continued.

\begin{tabular}{|c|c|c|c|}
\hline Putative paracrine factor & Symbol & Proposed function & Reference \\
\hline Periostin & POSTN & Cell proliferation & {$[18]$} \\
\hline Resistin & RETN & Cell signal & [19] \\
\hline Stromal derived factor & SDF & Cell development; angiogenesis & {$[18,22]$} \\
\hline Secreted frizzled related protein 1 & SFRP1 & Cell development & [19] \\
\hline Secreted frizzled related protein 2 & SFRP2 & $\begin{array}{l}\text { Cell development; tissue remodeling; } \\
\text { cytoprotection }\end{array}$ & {$[18]$} \\
\hline Transforming growth factor $\beta$ & TGF $\beta$ & Angiogenesis; cell proliferation & {$[18,20,24]$} \\
\hline Tissue inhibitor of metalloproteinase & TIMP & $\begin{array}{l}\text { Cell migration; extracellular matrix } \\
\text { degradation }\end{array}$ & {$[20]$} \\
\hline Tumor necrosis factor & TNF & $\begin{array}{l}\text { Cell proliferation; extracellular matrix } \\
\text { degradation }\end{array}$ & {$[20]$} \\
\hline Vascular endothelial growth factor & VEGF & $\begin{array}{l}\text { Angiogenesis; cytoprotection; } \\
\text { proliferation }\end{array}$ & {$[18,20,24]$} \\
\hline Von Willebrand factor & VWF & Cytoprotection & [19] \\
\hline
\end{tabular}

of HSCs in initial unfractionated BMMNC therapy with improvement in LVEF, subsequent studies have argued that HSCs did not directly differentiate into cardiomyocytes but instead became mature blood lineage cells after transplantation $[45,178]$. In particular, the administration of cell culture medium conditioned by MSCs overexpressing the gene AKT1 significantly reduced infarct size and cardiac apoptosis [179]. Cardiac protective growth factors, such as vascular endothelial growth factor (VEGF), hepatocyte growth factor (HGF), and insulin-like growth factor 1 (IGF-1), were also found in ADSC culture medium [95]. Nevertheless, evidence from genetic fate-mapping suggested that $\mathrm{c}-\mathrm{kit}^{+} \mathrm{CSC}$ and CDCs promote cardiomyocyte renewal after infarction without direct differentiation into cardiomyocytes in mice [113, 180, 181]. Collectively, the transplanted cells are proposed to produce soluble factors that can reduce scar formation and therefore ameliorate the niche for cardiomyocyte growth. [177]. Further identification of paracrine effectors may allow the development of defined, cell-free treatments based on proteins or small molecules [182]. Putative paracrine factors released by stem-like cells were listed in Table 2 .

Emerging experience has focused on unmodified derivations of adult stem cells, whereas optimization of paracrine profile of those implanted stem cells may regulate their therapeutic effects on injured myocardium [183]. For instance, granulocyte colony-stimulating factor (G-CSF) can accelerate healing process of cardiomyocyte regeneration via mobilization of endogenous BMCs into peripheral blood [184]. The relative efficacy of combination of G-CSF and BMCs administration was shown to be promising in several clinical studies $[185,186]$. Activation of stromal derived factor-1 (SDF-1), which contributes to myocardial homing of c-kit ${ }^{+}$CSCs, thereby may further improve the efficacious outcomes when combined with G-CSF treatment [187]. Alternatively, enhanced expression of IGF-1 in CSCs was shown to boost paracrine mediated regenerative capacity in infarcted myocardium by promoting transplanted cell proliferation and survival [183]. Based on that, predifferentiation of adult stem cells into cells with cardiopoietic phenotype may enhance their survival and engraftment during myocardial implantation [188]. A proof-of-concept study has thereby established a recombinant cardiogenic cocktail consisting of TGF $\beta 1$, BMP-4, activin-A, retinoic acid, IGF-1, FGF-2, $\alpha$ thrombin, and IL-6 to guide human MSCs into reparative cardiopoietic progenitor in a murine model [189].

\section{Future Prospects}

The legacy of these preclinical and clinical findings has promoted a consensus about the criteria by which regenerative stem cell therapies are assessed. The ideal candidate donor cell for myocardial reconstitution is a stem-like cell that can be easily obtained, has a robust proliferation capacity and a low risk of tumour formation and immune rejections, differentiates into functionally normal cardiomyocytes, and is suitable for minimally invasive clinical routines for transplantation. The use of stem cell therapy for heart disease is a complicated and still poorly understood process and requires a standard protocol for the characterization and quality control of stem cell preparation and comparable methodologies for cell delivery, dosage, timing, and clinical patient selection. The considerable advances in our current understanding have shown that stem cell therapy is safe, is moderately effective, and is mediated by indirect paracrine mechanisms. Dissection of the paracrine effectors induced by stem-like cells in cardiac regeneration will also pave the way for therapeutic interventions.

\section{Competing Interests}

Ming Hao, Richard Wang, and Wen Wang are current employees and stock option holders of Cellular Biomedicine Group (NASDAQ: CBMG).

\section{References}

[1] A. E. Moran, K. Y. Tzong, M. H. Forouzanfar et al., "Variations in ischemic heart disease burden by age, country, and income: 
the global burden of diseases, injuries, and risk factors 2010 study," Global Heart, vol. 9, no. 1, pp. 91-99, 2014.

[2] C. E. Murry, H. Reinecke, and L. M. Pabon, "Regeneration gaps : observations on stem cells and cardiac repair," Journal of the American College of Cardiology, vol. 47, no. 9, pp. 1777-1785, 2006.

[3] J. Stehlik, L. B. Edwards, A. Y. Kucheryavaya et al., "The registry of the international society for heart and lung transplantation: twenty-eighth adult heart transplant report-2011," The Journal of Heart and Lung Transplantation, vol. 30, no. 10, pp.1078-1094, 2011.

[4] J. P. Hellermann, S. J. Jacobsen, B. J. Gersh, R. J. Rodeheffer, G. S. Reeder, and V. L. Roger, "Heart failure after myocardial infarction: a review," American Journal of Medicine, vol. 113, no. 4, pp. 324-330, 2002.

[5] A. P. Beltrami, K. Urbanek, J. Kajstura et al., "Evidence that human cardiac myocytes divide after myocardial infarction," The New England Journal of Medicine, vol. 344, no. 23, pp. 17501757, 2001.

[6] F. Quaini, K. Urbanek, A. P. Beltrami et al., "Chimerism of the transplanted heart," The New England Journal of Medicine, vol. 346, no. 1, pp. 5-15, 2002.

[7] J. Kajstura, A. Leri, N. Finato, C. Di Loreto, C. A. Beltrami, and P. Anversa, "Myocyte proliferation in end-stage cardiac failure in humans," Proceedings of the National Academy of Sciences of the United States of America, vol. 95, no. 15, pp. 8801-8805, 1998.

[8] O. Bergmann, R. D. Bhardwaj, S. Bernard et al., "Evidence for cardiomyocyte renewal in humans," Science, vol. 324, no. 5923, pp. 98-102, 2009.

[9] P. C. H. Hsieh, V. F. M. Segers, M. E. Davis et al., "Evidence from a genetic fate-mapping study that stem cells refresh adult mammalian cardiomyocytes after injury," Nature Medicine, vol. 13, no. 8, pp. 970-974, 2007.

[10] A. Abbate, G. G. L. Biondi-Zoccai, D. L. Appleton et al., "Survival and cardiac remodeling benefits in patients undergoing late percutaneous coronary intervention of the infarct-related artery: evidence from a meta-analysis of randomized controlled trials," Journal of the American College of Cardiology, vol. 51, no. 9, pp. 956-964, 2008.

[11] M. Gyöngyösi, W. Wojakowski, E. P. Navarese, and L. À. Moye, "Meta-analyses of human cell-based cardiac regeneration therapies: controversies in meta-analyses results on cardiac cellbased regenerative studies," Circulation Research, vol. 118, no. 8 , pp. 1254-1263, 2016.

[12] A. R. Khan, T. A. Farid, A. Pathan et al., "Impact of cell therapy on myocardial perfusion and cardiovascular outcomes in patients with angina refractory to medical therapy: a systematic review and meta-analysis," Circulation Research, vol. 118, no. 6, pp. 984-993, 2016.

[13] M. Dominici, K. Le Blanc, I. Mueller et al., "Minimal criteria for defining multipotent mesenchymal stromal cells. The international society for cellular therapy position statement," Cytotherapy, vol. 8, no. 4, pp. 315-317, 2006.

[14] H. Oh, H. Ito, and S. Sano, "Challenges to success in heart failure: cardiac cell therapies in patients with heart diseases," Journal of Cardiology, vol. 68, no. 5, pp. 361-367, 2016.

[15] R. Sanz-Ruiz, E. Gutiérrez Ibañes, A. V. Arranz, M. E. Fernández Santos, P. L. S. Fernández, and F. Fernández-Avilés, "Phases I-III clinical trials using adult stem cells," Stem Cells International, vol. 2010, Article ID 579142, 12 pages, 2010.
[16] J. M. F. Wu, Y.-C. Hsueh, H.-J. Ch'ang et al., "Circulating cells contribute to cardiomyocyte regeneration after injury," Circulation Research, vol. 116, no. 4, pp. 633-641, 2015.

[17] J. O. Beitnes, O. Gjesdal, K. Lunde et al., "Left ventricular systolic and diastolic function improve after acute myocardial infarction treated with acute percutaneous coronary intervention, but are not influenced by intracoronary injection of autologous mononuclear bone marrow cells: a 3 year serial echocardiographic sub-study of the randomized-controlled ASTAMI study," European Journal of Echocardiography, vol. 12, no. 2, pp. 98-106, 2011.

[18] C. P. Hodgkinson, A. Bareja, J. A. Gomez, and V. J. Dzau, "Emerging concepts in paracrine mechanisms in regenerative cardiovascular medicine and biology," Circulation Research, vol. 118, no. 1, pp. 95-107, 2016.

[19] M. Korf-Klingebiel, T. Kempf, T. Sauer et al., "Bone marrow cells are a rich source of growth factors and cytokines: implications for cell therapy trials after myocardial infarction," European Heart Journal, vol. 29, no. 23, pp. 2851-2858, 2008.

[20] Y. Yao, J. Huang, Y. Geng et al., "Paracrine action of mesenchymal stem cells revealed by single cell gene profiling in infarcted murine hearts," PLoS ONE, vol. 10, no. 6, Article ID e0129164, 2015.

[21] K. S. Rao, A. Aronshtam, K. L. McElory-Yaggy et al., "Human epicardial cell-conditioned medium contains HGF/IgG complexes that phosphorylate RYK and protect against vascular injury," Cardiovascular Research, vol. 107, no. 2, pp. 277-286, 2015.

[22] K. Cheng, K. Malliaras, R. R. Smith et al., "Human cardiosphere-derived cells from advanced heart failure patients exhibit augmented functional potency in myocardial repair," JACC: Heart Failure, vol. 2, no. 1, pp. 49-61, 2014.

[23] S. Miyamoto, N. Kawaguchi, G. M. Ellison, R. Matsuoka, T. Shin'Oka, and H. Kurosawa, "Characterization of long-term cultured c-kit+ cardiac stem cells derived from adult rat hearts," Stem Cells and Development, vol. 19, no. 1, pp. 105-116, 2010.

[24] N. Kawaguchi, A. J. Smith, C. D. Waring et al., "c-Kitpos GATA4 high rat cardiac stem cells foster adult cardiomyocyte survival through IGF-1 paracrine signalling," PLoS ONE, vol. 5, no. 12, Article ID e14297, 2010.

[25] M. Lichtenauer, M. Mildner, A. Baumgartner et al., "Intravenous and intramyocardial injection of apoptotic white blood cell suspensions prevents ventricular remodelling by increasing elastin expression in cardiac scar tissue after myocardial infarction," Basic Research in Cardiology, vol. 106, no. 4, pp. 645-655, 2011.

[26] L. Barile, V. Lionetti, E. Cervio et al., "Extracellular vesicles from human cardiac progenitor cells inhibit cardiomyocyte apoptosis and improve cardiac function after myocardial infarction," Cardiovascular Research, vol. 103, no. 4, pp. 530-541, 2014.

[27] A. G.-E. Ibrahim, K. Cheng, and E. Marbán, "Exosomes as critical agents of cardiac regeneration triggered by cell therapy," Stem Cell Reports, vol. 2, no. 5, pp. 606-619, 2014.

[28] E. Tseliou, G. De Couto, J. Terrovitis et al., "Angiogenesis, cardiomyocyte proliferation and anti-fibrotic effects underlie structural preservation post-infarction by intramyocardiallyinjected cardiospheres," PLoS ONE, vol. 9, no. 2, Article ID e88590, 2014.

[29] M. Buckingham and D. Montarras, "Skeletal muscle stem cells," Current Opinion in Genetics \& Development, vol. 18, no. 4, pp. 330-336, 2008. 
[30] J. C. Chachques, C. Acar, J. Herreros et al., "Cellular cardiomyoplasty: clinical application," The Annals of Thoracic Surgery, vol. 77, no. 3, pp. 1121-1130, 2004.

[31] P. Menasché, A. A. Hagège, M. Scorsin et al., "Myoblast transplantation for heart failure," The Lancet, vol. 357, no. 9252, pp. 279-280, 2001.

[32] P. Farahmand, T. Y. Y. Lai, R. D. Weisel et al., "Skeletal myoblasts preserve remote matrix architecture and global function when implanted early or late after coronary ligation into infarcted or remote myocardium," Circulation, vol. 118, no. 14, pp. S130-S137, 2008.

[33] J. Pouly, A. A. Hagège, J.-T. Vilquin et al., "Does the functional efficacy of skeletal myoblast transplantation extend to nonischemic cardiomyopathy?" Circulation, vol. 110, no. 12, pp. 16261631, 2004.

[34] K.-L. He, G.-H. Yi, W. Sherman et al., "Autologous skeletal myoblast transplantation improved hemodynamics and left ventricular function in chronic heart failure dogs," The Journal of Heart and Lung Transplantation, vol. 24, no. 11, pp. 1940-1949, 2005.

[35] A. Asakura, M. Komaki, and M. A. Rudnicki, "Muscle satellite cells are multipotential stem cells that exhibit myogenic, osteogenic, and adipogenic differentiation," Differentiation, vol. 68, no. 4-5, pp. 245-253, 2001.

[36] Y. Iijima, T. Nagai, M. Mizukami et al., "Beating is necessary for transdifferentiation of skeletal muscle-derived cells into cardiomyocytes," The FASEB Journal, vol. 17, no. 10, pp. 13611363, 2003.

[37] L. Formigli, F. Francini, A. Tani et al., "Morphofunctional integration between skeletal myoblasts and adult cardiomyocytes in coculture is favored by direct cell-cell contacts and relaxin treatment," American Journal of Physiology-Cell Physiology, vol. 288, no. 4, pp. C795-C804, 2005.

[38] H. Reinecke, G. H. MacDonald, S. D. Hauschka, and C. E. Murry, "Electromechanical coupling between skeletal and cardiac muscle. Implications for infarct repair," The Journal of Cell Biology, vol. 149, no. 3, pp. 731-740, 2000.

[39] P. Menasché, A. A. Hagège, J.-T. Vilquin et al., "Autologous skeletal myoblast transplantation for severe postinfarction left ventricular dysfunction," Journal of the American College of Cardiology, vol. 41, no. 7, pp. 1078-1083, 2003.

[40] P. Menasché, O. Alfieri, S. Janssens et al., “The myoblast autologous grafting in ischemic cardiomyopathy (MAGIC) trial: first randomized placebo-controlled study of myoblast transplantation," Circulation, vol. 117, no. 9, pp. 1189-1200, 2008.

[41] H. Reinecke, V. Poppa, and C. E. Murry, "Skeletal muscle stem cells do not transdifferentiate into cardiomyocytes after cardiac grafting," Journal of Molecular and Cellular Cardiology, vol. 34, no. 2, pp. 241-249, 2002.

[42] P. Müller, P. Pfeiffer, J. Koglin et al., "Cardiomyocytes of noncardiac origin in myocardial biopsies of human transplanted hearts," Circulation, vol. 106, no. 1, pp. 31-35, 2002.

[43] D. Orlic, J. Kajstura, S. Chimenti et al., "Mobilized bone marrow cells repair the infarcted heart, improving function and survival," Proceedings of the National Academy of Sciences of the United States of America, vol. 98, no. 18, pp. 10344-10349, 2001.

[44] M. A. Sussman and C. E. Murry, "Bones of contention: marrowderived cells in myocardial regeneration," Journal of Molecular and Cellular Cardiology, vol. 44, no. 6, pp. 950-953, 2008.

[45] L. B. Balsam, A. J. Wagers, J. L. Christensen, T. Kofidis, I. L. Weissmann, and R. C. Robbins, "Haematopoietic stem cells adopt mature haematopoietic fates in ischaemic myocardium," Nature, vol. 428, no. 6983, pp. 668-673, 2004.

[46] M. Yousef, C. M. Schannwell, M. Köstering, T. Zeus, M. Brehm, and B. E. Strauer, "The BALANCE Study: clinical benefit and long-term outcome after intracoronary autologous bone marrow cell transplantation in patients with acute myocardial infarction," Journal of the American College of Cardiology, vol. 53, no. 24, pp. 2262-2269, 2009.

[47] M. F. Pittenger and B. J. Martin, "Mesenchymal stem cells and their potential as cardiac therapeutics," Circulation Research, vol. 95, no. 1, pp. 9-20, 2004.

[48] A. Armiñán, C. Gandía, J. M. García-Verdugo et al., "Mesenchymal stem cells provide better results than hematopoietic precursors for the treatment of myocardial infarction," Journal of the American College of Cardiology, vol. 55, no. 20, pp. 22442253, 2010.

[49] C. Toma, M. F. Pittenger, K. S. Cahill, B. J. Byrne, and P. D. Kessler, "Human mesenchymal stem cells differentiate to a cardiomyocyte phenotype in the adult murine heart," Circulation, vol. 105, no. 1, pp. 93-98, 2002.

[50] T. Asahara, H. Masuda, T. Takahashi et al., "Bone marrow origin of endothelial progenitor cells responsible for postnatal vasculogenesis in physiological and pathological neovascularization," Circulation Research, vol. 85, no. 3, pp. 221-228, 1999.

[51] J. M. Hill, G. Zalos, J. P. J. Halcox et al., "Circulating endothelial progenitor cells, vascular function, and cardiovascular risk," The New England Journal of Medicine, vol. 348, no. 7, pp. 593-600, 2003.

[52] S. Dimmeler and A. M. Zeiher, "Cell therapy of acute myocardial infarction: open questions," Cardiology, vol. 113, no. 3, pp. 155-160, 2009.

[53] J. R. Crosby, W. E. Kaminski, G. Schatteman et al., "Endothelial cells of hematopoietic origin make a significant contribution to adult blood vessel formation," Circulation Research, vol. 87, no. 9, pp. 728-730, 2000.

[54] K. Malliaras and E. Marbán, "Cardiac cell therapy: where we've been, where we are, and where we should be headed," British Medical Bulletin, vol. 98, no. 1, pp. 161-185, 2011.

[55] D. Orlic, J. Kajstura, S. Chimenti et al., "Bone marrow cells regenerate infarcted myocardium," Nature, vol. 410, no. 6829, pp. 701-705, 2001.

[56] B. E. Strauer, M. Brehm, T. Zeus et al., "Intracoronary, human autologous stem cell transplantation for myocardial regeneration following myocardial infarction," Deutsche Medizinische Wochenschrift, vol. 126, no. 34-35, pp. 932-938, 2001.

[57] H.-F. Tse, Y.-L. Kwong, J. K. F. Chan, G. Lo, C.-L. Ho, and C.-P. $\mathrm{Lau}$, "Angiogenesis in ischaemic myocardium by intramyocardial autologous bone marrow mononuclear cell implantation," The Lancet, vol. 361, no. 9351, pp. 47-49, 2003.

[58] E. C. Perin, H. F. R. Dohmann, R. Borojevic et al., "Transendocardial, autologous bone marrow cell transplantation for severe, chronic ischemic heart failure," Circulation, vol. 107, no. 18, pp. 2294-2302, 2003.

[59] B. Assmus, V. Schächinger, C. Teupe et al., "Transplantation of progenitor cells and regeneration enhancement in acute myocardial infarction (TOPCARE-AMI)," Circulation, vol. 106, no. 24, pp. 3009-3017, 2002.

[60] D. M. Leistner, U. Fischer-Rasokat, J. Honold et al., "Transplantation of progenitor cells and regeneration enhancement in acute myocardial infarction (TOPCARE-AMI): final 5-year results suggest long-term safety and efficacy," Clinical Research in Cardiology, vol. 100, no. 10, pp. 925-934, 2011. 
[61] G. P. Meyer, K. C. Wollert, J. Lotz et al., "Intracoronary bone marrow cell transfer after myocardial infarction: eighteen months' follow-up data from the randomized, controlled BOOST (BOne marrOw transfer to enhance ST-elevation infarct regeneration) trial," Circulation, vol. 113, no. 10, pp. 12871294, 2006.

[62] K. Lunde, S. Solheim, S. Aakhus et al., "Intracoronary injection of mononuclear bone marrow cells in acute myocardial infarction," The New England Journal of Medicine, vol. 355, no. 12, pp. 1199-1209, 2006.

[63] S. Janssens, C. Dubois, J. Bogaert et al., "Autologous bone marrow-derived stem-cell transfer in patients with ST-segment elevation myocardial infarction: double-blind, randomised controlled trial," The Lancet, vol. 367, no. 9505, pp. 113-121, 2006.

[64] J. O. Beitnes, E. Hopp, K. Lunde et al., "Long-term results after intracoronary injection of autologous mononuclear bone marrow cells in acute myocardial infarction: the ASTAMI randomised, controlled study," Heart, vol. 95, no. 24, pp. 19831989, 2009.

[65] J. H. Traverse, T. D. Henry, C. J. Pepine et al., "Effect of the use and timing of bone marrow mononuclear cell delivery on left ventricular function after acute myocardial infarction: the TIME randomized trial," JAMA, vol. 308, no. 22, pp. 2380-2389, 2012.

[66] M. Gyöngyösi, I. Lang, M. Dettke et al., "Combined delivery approach of bone marrow mononuclear stem cells early and late after myocardial infarction: the MYSTAR prospective, randomized study," Nature Clinical Practice Cardiovascular Medicine, vol. 6, no. 1, pp. 70-81, 2009.

[67] M. Tendera, W. Wojakowski, W. Ruyłło et al., "Intracoronary infusion of bone marrow-derived selected CD34 +CXCR4+ cells and non-selected mononuclear cells in patients with acute STEMI and reduced left ventricular ejection fraction: results of randomized, multicentre Myocardial Regeneration by Intracoronary Infusion of Selected Population of Stem Cells in Acute Myocardial Infarction (REGENT) Trial," European Heart Journal, vol. 30, no. 11, pp. 1313-1321, 2009.

[68] B.-E. Strauer, M. Yousef, and C. M. Schannwell, “The acute and long-term effects of intracoronary Stem cell Transplantation in 191 patients with chronic heARt failure: the STAR-heart study," European Journal of Heart Failure, vol. 12, no. 7, pp. 721-729, 2010.

[69] D. Sürder, R. Manka, V. Lo Cicero et al., "Intracoronary injection of bone marrow-derived mononuclear cells early or late after acute myocardial infarction: effects on global left ventricular function," Circulation, vol. 127, no. 19, pp. 1968-1979, 2013.

[70] R. E. Michler, "Stem cell therapy for heart failure," Cardiology in Review, vol. 22, no. 3, pp. 105-116, 2014.

[71] V. Jeevanantham, M. Butler, A. Saad, A. Abdel-Latif, E. K. Zuba-Surma, and B. Dawn, "Adult bone marrow cell therapy improves survival and induces long-term improvement in cardiac parameters: a systematic review and meta-analysis," Circulation, vol. 126, no. 5, pp. 551-568, 2012.

[72] H. Zimmet, P. Porapakkham, P. Porapakkham et al., "Shortand long-term outcomes of intracoronary and endogenously mobilized bone marrow stem cells in the treatment of STsegment elevation myocardial infarction: a meta-analysis of randomized control trials," European Journal of Heart Failure, vol. 14, no. 1, pp. 91-105, 2012.

[73] C. Griesel, H.-G. Heuft, D. Herrmann et al., "Good manufacturing practice-compliant validation and preparation of BM cells for the therapy of acute myocardial infarction," Cytotherapy, vol. 9, no. 1, pp. 35-43, 2007.

[74] S. K. Sanganalmath and R. Bolli, "Cell therapy for heart failure: a comprehensive overview of experimental and clinical studies, current challenges, and future directions," Circulation Research, vol. 113, no. 6, pp. 810-834, 2013.

[75] M. F. Pittenger, A. M. Mackay, S. C. Beck et al., "Multilineage potential of adult human mesenchymal stem cells," Science, vol. 284, no. 5411, pp. 143-147, 1999.

[76] S. Aggarwal and M. F. Pittenger, "Human mesenchymal stem cells modulate allogeneic immune cell responses," Blood, vol. 105, no. 4, pp. 1815-1822, 2005.

[77] J.-F. Liu, B.-W. Wang, H.-F. Hung, H. Chang, and K.-G. Shyu, "Human mesenchymal stem cells improve myocardial performance in a splenectomized rat model of chronic myocardial infarction," Journal of the Formosan Medical Association, vol. 107, no. 2, pp. 165-174, 2008.

[78] L. Li, S. Zhang, Y. Zhang, B. Yu, Y. Xu, and Z. Guan, "Paracrine action mediate the antifibrotic effect of transplanted mesenchymal stem cells in a rat model of global heart failure," Molecular Biology Reports, vol. 36, no. 4, pp. 725-731, 2009.

[79] M. Mazo, J. J. Gavira, G. Abizanda et al., “Transplantation of mesenchymal stem cells exerts a greater long-term effect than bone marrow mononuclear cells in a chronic myocardial infarction model in rat," Cell Transplantation, vol. 19, no. 3, pp. 313-328, 2010.

[80] J. M. Hare, J. H. Traverse, T. D. Henry et al., "A randomized, double-blind, placebo-controlled, dose-escalation study of intravenous adult human mesenchymal stem cells (prochymal) after acute myocardial infarction," Journal of the American College of Cardiology, vol. 54, no. 24, pp. 2277-2286, 2009.

[81] V. Karantalis, D. L. Difede, G. Gerstenblith et al., "Autologous mesenchymal stem cells produce concordant improvements in regional function, tissue perfusion, and fibrotic burden when administered to patients undergoing coronary artery bypass grafting: the Prospective Randomized Study of Mesenchymal Stem Cell Therapy in Patients Undergoing Cardiac Surgery (PROMETHEUS) trial," Circulation Research, vol. 114, no. 8, pp. 1302-1310, 2014.

[82] J. M. Hare, J. E. Fishman, G. Gerstenblith et al., "Comparison of allogeneic vs autologous bone marrow-derived mesenchymal stem cells delivered by transendocardial injection in patients with ischemic cardiomyopathy: the POSEIDON randomized trial," JAMA, vol. 308, no. 22, pp. 2369-2379, 2012.

[83] The TRansendocardial Stem Cell Injection Delivery Effects on Neomyogenesis STudy (The TRIDENT Study) (Trident) (NCT02013674), https://www.clinicaltrials.gov/.

[84] L. R. Gao, Y. Chen, N. K. Zhang et al., "Intracoronary infusion of Wharton's jelly-derived mesenchymal stem cells in acute myocardial infarction: double-blind, randomized controlled trial," BMC Medicine, vol. 13, article 162, 2015.

[85] J.-W. Lee, S.-H. Lee, Y.-J. Youn et al., "A randomized, openlabel, multicenter trial for the safety and efficacy of adult mesenchymal stem cells after acute myocardial infarction," Journal of Korean Medical Science, vol. 29, no. 1, pp. 23-31, 2014.

[86] "A Study of Allogeneic Mesenchymal Bone Marrow Cells in Subjects With ST Segment Elevation Myocardial Infarction (STEMI) (NCT01770613)," https://clinicaltrials.gov/.

[87] "RELIEF(A Randomized,Open labEled, muLticenter Trial for Safety and Efficacy of Intracoronary Adult Human Mesenchymal stEm Cells Acute Myocardial inFarction) (NCT01652209)," https://clinicaltrials.gov/. 
[88] X. Bai, Y. Yan, Y.-H. Song et al., "Both cultured and freshly isolated adipose tissue-derived stem cells enhance cardiac function after acute myocardial infarction," European Heart Journal, vol. 31, no. 4, pp. 489-501, 2010.

[89] B. Lindroos, R. Suuronen, and S. Miettinen, "The potential of adipose stem cells in regenerative medicine," Stem Cell Reviews and Reports, vol. 7, no. 2, pp. 269-291, 2011.

[90] R. Yañez, M. L. Lamana, J. García-Castro, I. Colmenero, M. Ramírez, and J. A. Bueren, "Adipose tissue-derived mesenchymal stem cells have in vivo immunosuppressive properties applicable for the control of the graft-versus-host disease," Stem Cells, vol. 24, no. 11, pp. 2582-2591, 2006.

[91] V. Planat-Bénard, C. Menard, M. André et al., "Spontaneous cardiomyocyte differentiation from adipose tissue stroma cells," Circulation Research, vol. 94, no. 2, pp. 223-229, 2004.

[92] A. Miranville, C. Heeschen, C. Sengenès, C. A. Curat, R. Busse, and A. Bouloumié, "Improvement of postnatal neovascularization by human adipose tissue-derived stem cells," Circulation, vol. 110, no. 3, pp. 349-355, 2004.

[93] T. Rada, R. L. Reis, and M. E. Gomes, "Distinct stem cells subpopulations isolated from human adipose tissue exhibit different chondrogenic and osteogenic differentiation potential," Stem Cell Reviews and Reports, vol. 7, no. 1, pp. 64-76, 2011.

[94] M. Mazo, V. Planat-Bénard, G. Abizanda et al., "Transplantation of adipose derived stromal cells is associated with functional improvement in a rat model of chronic myocardial infarction," European Journal of Heart Failure, vol. 10, no. 5, pp. 454-462, 2008.

[95] L. Wang, J. Deng, W. Tian et al., "Adipose-derived stem cells are an effective cell candidate for treatment of heart failure: an MR imaging study of rat hearts," American Journal of Physiology Heart and Circulatory Physiology, vol. 297, no. 3, pp. H1020H1031, 2009.

[96] Randomized Clinical Trial of Adipose-Derived Stem Cells in the Treatment of Pts With ST-elevation Myocardial Infarction (NCT00442806), https://www.clinicaltrials.gov/.

[97] "CSCC_ASC Therapy in Patients with Severe Heart Failure (NCT02387723)," https://clinicaltrials.gov/.

[98] E. C. Perin, R. Sanz-Ruiz, P. L. Sánchez et al., "Adipose-derived regenerative cells in patients with ischemic cardiomyopathy: the PRECISE Trial," American Heart Journal, vol. 168, no. 1, pp. 88.e2-95.e2, 2014.

[99] T. A. Deisher, "Cardiac-derived stem cells," IDrugs, vol. 3, no. 6, pp. 649-653, 2000.

[100] I. L. Weissman, D. J. Anderson, and F. Gage, "Stem and progenitor cells: origins, phenotypes, lineage commitments, and transdifferentiations," Annual Review of Cell and Developmental Biology, vol. 17, pp. 387-403, 2001.

[101] A. P. Beltrami, L. Barlucchi, D. Torella et al., "Adult cardiac stem cells are multipotent and support myocardial regeneration," Cell, vol. 114, no. 6, pp. 763-776, 2003.

[102] H. Oh, S. B. Bradfute, T. D. Gallardo et al., "Cardiac progenitor cells from adult myocardium: homing, differentiation, and fusion after infarction," Proceedings of the National Academy of Sciences of the United States of America, vol. 100, no. 21, pp. 12313-12318, 2003.

[103] K. L. Laugwitz, A. Moretti, J. Lam et al., "Postnatal isl1+ cardioblasts enter fully differentiated cardiomyocyte lineages," Nature, vol. 433, pp. 647-653, 2005.

[104] H. C. Ott, T. S. Matthiesen, J. Brechtken et al., "The adult human heart as a source for stem cells: repair strategies with embryonic-like progenitor cells," Nature Clinical Practice Cardiovascular Medicine, vol. 4, supplement 1, pp. S27-S39, 2007.

[105] M. Noseda, M. Harada, S. McSweeney et al., "PDGFR $\alpha$ demarcates the cardiogenic clonogenic $\mathrm{Scal}^{+}$stem/progenitor cell in adult murine myocardium," Nature Communications, vol. 6, article 6930, 2015.

[106] C. M. Martin, A. P. Meeson, S. M. Robertson et al., "Persistent expression of the ATP-binding cassette transporter, Abcg2, identifies cardiac SP cells in the developing and adult heart," Developmental Biology, vol. 265, no. 1, pp. 262-275, 2004.

[107] E. Messina, L. De Angelis, G. Frati et al., "Isolation and expansion of adult cardiac stem cells from human and murine heart," Circulation Research, vol. 95, no. 9, pp. 911-921, 2004.

[108] P. Menasché and V. Vanneaux, "Stem cells for the treatment of heart failure," Current Research in Translational Medicine, vol. 64, no. 2, pp. 97-106, 2016.

[109] M. T.-L. Discorde, S. Prost, E. Nandrot, and M. Kirszenbaum, "Spatial and temporal mapping of c-kit and its ligand, stem cell factor expression during human embryonic haemopoiesis," British Journal of Haematology, vol. 107, no. 2, pp. 247-253, 1999.

[110] T. Kunisada, H. Yoshida, H. Yamazaki et al., "Transgene expression of steel factor in the basal layer of epidermis promotes survival, proliferation, differentiation and migration of melanocyte precursors," Development, vol. 125, no. 15, pp. 2915-2923, 1998.

[111] B. Nadal-Ginard, J. Kajstura, A. Leri, and P. Anversa, "Myocyte death, growth, and regeneration in cardiac hypertrophy and failure," Circulation Research, vol. 92, no. 2, pp. 139-150, 2003.

[112] P. P. Zwetsloot, A. M. D. Végh, S. J. Jansen Of Lorkeers et al., "Cardiac stem cell treatment in myocardial infarction: a systematic review and meta-analysis of preclinical studies," Circulation Research, vol. 118, no. 8, pp. 1223-1232, 2016.

[113] X. L. Tang, Q. Li, G. Rokosh et al., "Long-term outcome of administration of c-kit(POS) cardiac progenitor cells after acute myocardial infarction: transplanted cells do not become cardiomyocytes, but structural and functional improvement and proliferation of endogenous cells persist for at least one year," Circulation Research, vol. 118, pp. 1091-1105, 2016.

[114] R. Bolli, A. R. Chugh, D. D’Amario et al., "Cardiac stem cells in patients with ischaemic cardiomyopathy (SCIPIO): initial results of a randomised phase 1 trial," The Lancet, vol. 378, no. 9806, pp. 1847-1857, 2011.

[115] "Combination of Mesenchymal and C-kit+ Cardiac Stem Cells as Regenerative Therapy for Heart Failure (CONCERT-HF) (NCT02501811)," https://clinicaltrials.gov/.

[116] M. T. Armstrong, D. Y. Lee, and P. B. Armstrong, "Regulation of proliferation of the fetal myocardium," Developmental Dynamics, vol. 219, no. 2, pp. 226-236, 2000.

[117] S. K. Nilsson and P. J. Simmons, "Transplantable stem cells: home to specific niches," Current Opinion in Hematology, vol. 11, no. 2, pp. 102-106, 2004.

[118] T.-S. Li, K. Cheng, K. Malliaras et al., "Direct comparison of different stem cell types and subpopulations reveals superior paracrine potency and myocardial repair efficacy with cardiosphere-derived cells," Journal of the American College of Cardiology, vol. 59, no. 10, pp. 942-953, 2012.

[119] R. R. Makkar, R. R. Smith, K. Cheng et al., "Intracoronary cardiosphere-derived cells for heart regeneration after myocardial infarction (CADUCEUS): a prospective, randomised phase 1 trial," The Lancet, vol. 379, no. 9819, pp. 895-904, 2012. 
[120] "AutoLogous Human Cardiac-Derived Stem Cell to Treat Ischemic Cardiomyopathy (ALCADIA) (ALCADIA) (NCT00981006)," https://clinicaltrials.gov/.

[121] K. Malliaras, R. R. Makkar, R. R. Smith et al., "Intracoronary cardiosphere-derived cells after myocardial infarction : evidence of therapeutic regeneration in the final 1-year results of the CADUCEUS trial (CArdiosphere-derived aUtologous stem CElls to reverse ventricUlar dySfunction)," Journal of the American College of Cardiology, vol. 63, no. 2, pp. 110-122, 2014.

[122] P. V. Johnston, T. Sasano, K. Mills et al., "Engraftment, differentiation, and functional benefits of autologous cardiospherederived cells in porcine ischemic cardiomyopathy," Circulation, vol. 120, no. 12, pp. 1075-1083, 2009.

[123] K. Tateishi, E. Ashihara, S. Honsho et al., "Human cardiac stem cells exhibit mesenchymal features and are maintained through Akt/GSK-3 $\beta$ signaling," Biochemical and Biophysical Research Communications, vol. 352, no. 3, pp. 635-641, 2007.

[124] S. J. Jansen of Lorkeers, J. E. C. Eding, H. M. Vesterinen et al., "Similar effect of autologous and allogeneic cell therapy for ischemic heart disease: systematic review and meta-analysis of large animal studies," Circulation Research, vol. 116, no. 1, pp. 8086, 2015.

[125] "Allogeneic Heart Stem Cells to Achieve Myocardial Regeneration (ALLSTAR) (NCT01458405)," https://clinicaltrials.gov/.

[126] "Dilated cardiomYopathy iNtervention with Allogeneic MyocardIally-regenerative Cells (DYNAMIC) (DYNAMIC) (NCT02293603)," https://clinicaltrials.gov/.

[127] "HOPE-Duchenne (Halt cardiomyOPathy progression in Duchenne) (HOPE) (NCT02485938)," https://clinicaltrials .gov/.

[128] C. E. Murry and G. Keller, "Differentiation of embryonic stem cells to clinically relevant populations: lessons from embryonic development," Cell, vol. 132, no. 4, pp. 661-680, 2008.

[129] I. Huber, I. Itzhaki, O. Caspi et al., "Identification and selection of cardiomyocytes during human embryonic stem cell differentiation," The FASEB Journal, vol. 21, no. 10, pp. 2551-2563, 2007.

[130] K. R. Boheler, D. G. Crider, Y. Tarasova, and V. A. Maltsev, "Cardiomyocytes derived from embryonic stem cells," Methods in Molecular Medicine, vol. 108, pp. 417-435, 2005.

[131] A. C. Fijnvandraat, A. C. G. Van Ginneken, C. A. Schumacher et al., "Cardiomyocytes purified from differentiated embryonic stem cells exhibit characteristics of early chamber myocardium," Journal of Molecular and Cellular Cardiology, vol. 35, no. 12, pp. 1461-1472, 2003.

[132] A. C. Fijnvandraat, R. H. Lekanne Deprez, and A. F. M. Moorman, "Development of heart muscle-cell diversity: a help or a hindrance for phenotyping embryonic stem cell-derived cardiomyocytes," Cardiovascular Research, vol. 58, no. 2, pp. 303-312, 2003.

[133] T. J. Nelson, Z.-D. Ge, J. Van Orman et al., "Improved cardiac function in infarcted mice after treatment with pluripotent embryonic stem cells," The Anatomical Record-Part A Discoveries in Molecular, Cellular, and Evolutionary Biology, vol. 288, no. 11, pp. 1216-1224, 2006.

[134] H. Qiao, H. Zhang, S. Yamanaka et al., "Long-term improvement in postinfarct left ventricular global and regional contractile function is mediated by embryonic stem cell-derived cardiomyocytes," Circulation: Cardiovascular Imaging, vol. 4, no. 1, pp. 33-41, 2011.

[135] R. Passier, L. W. Van Laake, and C. L. Mummery, "Stem-cellbased therapy and lessons from the heart," Nature, vol. 453, no. 7193, pp. 322-329, 2008.
[136] J. Nussbaum, E. Minami, M. A. Laflamme et al., "Transplantation of undifferentiated murine embryonic stem cells in the heart: teratoma formation and immune response," FASEB Journal, vol. 21, no. 7, pp. 1345-1357, 2007.

[137] Transplantation of Human Embryonic Stem Cell-derived Progenitors in Severe Heart Failure (ESCORT) (NCT02057900), https://www.clinicaltrials.gov/.

[138] K. Takahashi, K. Tanabe, M. Ohnuki et al., "Induction of pluripotent stem cells from adult human fibroblasts by defined factors," Cell, vol. 131, no. 5, pp. 861-872, 2007.

[139] G. Narazaki, H. Uosaki, M. Teranishi et al., "Directed and systematic differentiation of cardiovascular cells from mouse induced pluripotent stem cells," Circulation, vol. 118, no. 5, pp. 498-506, 2008.

[140] J. Zhang, G. F. Wilson, A. G. Soerens et al., "Functional cardiomyocytes derived from human induced pluripotent stem cells," Circulation Research, vol. 104, no. 4, pp. e30-e41, 2009.

[141] L. Yang, M. H. Soonpaa, E. D. Adler et al., "Human cardiovascular progenitor cells develop from a $\mathrm{KDR}^{+}$embryonic-stemcell-derived population," Nature, vol. 453, no. 7194, pp. 524-528, 2008.

[142] X. Q. Xu, R. Graichen, S. Y. Soo et al., "Chemically defined medium supporting cardiomyocyte differentiation of human embryonic stem cells," Differentiation, vol. 76, no. 9, pp. 958970, 2008.

[143] M. A. Laflamme, K. Y. Chen, A. V. Naumova et al., "Cardiomyocytes derived from human embryonic stem cells in prosurvival factors enhance function of infarcted rat hearts," Nature Biotechnology, vol. 25, no. 9, pp. 1015-1024, 2007.

[144] C. Freund and C. L. Mummery, "Prospects for pluripotent stem cell-derived cardiomyocytes in cardiac cell therapy and as disease models," Journal of Cellular Biochemistry, vol. 107, no. 4, pp. 592-599, 2009.

[145] J. A. Efe, S. Hilcove, J. Kim et al., "Conversion of mouse fibroblasts into cardiomyocytes using a direct reprogramming strategy," Nature Cell Biology, vol. 13, no. 3, pp. 215-222, 2011.

[146] M. Ieda, J.-D. Fu, P. Delgado-Olguin et al., "Direct reprogramming of fibroblasts into functional cardiomyocytes by defined factors," Cell, vol. 142, no. 3, pp. 375-386, 2010.

[147] Derivation of Human Induced Pluripotent Stem (iPS) Cells to Heritable Cardiac Arrhythmias (NCT02413450), https://www.clinicaltrials.gov/.

[148] "Blood Collection From Healthy Volunteers and Patients for the Production of Clinical Grade Induced Pluripotent Stem Cell (iPSC) Products (NCT02056613)," https://clinicaltrials.gov/.

[149] M. A. Laflamme and C. E. Murry, "Regenerating the heart," Nature Biotechnology, vol. 23, no. 7, pp. 845-856, 2005.

[150] J. Terrovitis, R. Lautamäki, M. Bonios et al., "Noninvasive quantification and optimization of acute cell retention by in vivo positron emission tomography after intramyocardial cardiacderived stem cell delivery," Journal of the American College of Cardiology, vol. 54, no. 17, pp. 1619-1626, 2009.

[151] A. C. P. Diederichsen, J. E. Møller, P. Thayssen et al., "Changes in left ventricular filling patterns after repeated injection of autologous bone marrow cells in heart failure patients," Scandinavian Cardiovascular Journal, vol. 44, no. 3, pp. 139-145, 2010.

[152] Q. Yu, Q. Li, R. Na et al., "Impact of repeated intravenous bone marrow mesenchymal stem cells infusion on myocardial collagen network remodeling in a rat model of doxorubicin-induced dilated cardiomyopathy," Molecular and Cellular Biochemistry, vol. 387, no. 1-2, pp. 279-285, 2014. 
[153] H. Reich, E. Tseliou, G. de Couto et al., "Repeated transplantation of allogeneic cardiosphere-derived cells boosts therapeutic benefits without immune sensitization in a rat model of myocardial infarction," The Journal of Heart and Lung Transplantation, vol. 35, no. 11, pp. 1348-1357, 2016.

[154] T. Freyman, G. Polin, H. Osman et al., "A quantitative, randomized study evaluating three methods of mesenchymal stem cell delivery following myocardial infarction," European Heart Journal, vol. 27, no. 9, pp. 1114-1122, 2006.

[155] Prochymal ${ }^{\circledR}$ (Human Adult Stem Cells) Intravenous Infusion Following Acute Myocardial Infarction (AMI) (NCT00877903), https://www.clinicaltrials.gov/.

[156] A. N. Patel, L. Geffner, R. F. Vina et al., "Surgical treatment for congestive heart failure with autologous adult stem cell transplantation: a prospective randomized study," The Journal of Thoracic and Cardiovascular Surgery, vol. 130, no. 6, pp. 16311638, 2005.

[157] T. Siminiak, D. Fiszer, O. Jerzykowska et al., "Percutaneous trans-coronary-venous transplantation of autologous skeletal myoblasts in the treatment of post-infarction myocardial contractility impairment: the POZNAN trial," European Heart Journal, vol. 26, no. 12, pp. 1188-1195, 2005.

[158] S. Charwat, I. Lang, M. Dettke et al., "Effect of intramyocardial delivery of autologous bone marrow mononuclear stem cells on the regional myocardial perfusion. NOGA-guided subanalysis of the MYSTAR prospective randomised study," Thrombosis and Haemostasis, vol. 103, no. 3, pp. 564-571, 2010.

[159] Q. Li, Y. Guo, Q. Ou et al., "Intracoronary administration of cardiac stem cells in mice: a new, improved technique for cell therapy in murine models," Basic Research in Cardiology, vol. 106, no. 5, pp. 849-864, 2011.

[160] J. Tongers, D. W. Losordo, and U. Landmesser, "Stem and progenitor cell-based therapy in ischaemic heart disease: promise, uncertainties, and challenges," European Heart Journal, vol. 32, no. 10, pp. 1197-1206, 2011.

[161] M. Hofmann, K. C. Wollert, G. P. Meyer et al., "Monitoring of bone marrow cell homing into the infarcted human myocardium," Circulation, vol. 111, no. 17, pp. 2198-2202, 2005.

[162] J. V. Terrovitis, R. R. Smith, and E. Marbán, “Assessment and optimization of cell engraftment after transplantation into the heart," Circulation Research, vol. 106, no. 3, pp. 479-494, 2010.

[163] K. L. Christman and R. J. Lee, "Biomaterials for the treatment of myocardial infarction," Journal of the American College of Cardiology, vol. 48, no. 5, pp. 907-913, 2006.

[164] C. E. Murry, L. J. Field, and P. Menasché, "Cell-based cardiac repair: reflections at the 10 -year point," Circulation, vol. 112, no. 20, pp. 3174-3183, 2005.

[165] J. Müller-Ehmsen, P. Whittaker, R. A. Kloner et al., "Survival and development of neonatal rat cardiomyocytes transplanted into adult myocardium," Journal of Molecular and Cellular Cardiology, vol. 34, no. 2, pp. 107-116, 2002.

[166] L. Zeng, Q. Hu, X. Wang et al., "Bioenergetic and functional consequences of bone marrow-derived multipotent progenitor cell transplantation in hearts with postinfarction left ventricular remodeling," Circulation, vol. 115, no. 14, pp. 1866-1875, 2007.

[167] C. Lang, S. Lehner, A. Todica et al., "In-vivo comparison of the acute retention of stem cell derivatives and fibroblasts after intramyocardial transplantation in the mouse model," European Journal of Nuclear Medicine and Molecular Imaging, vol. 41, no. 12, pp. 2325-2336, 2014.
[168] R. Rakian, T. J. Block, S. M. Johnson et al., "Native extracellular matrix preserves mesenchymal stem cell 'stemness' and differentiation potential under serum-free culture conditions," Stem Cell Research \& Therapy, vol. 6, no. 1, article 235, 2015.

[169] V. Schächinger, S. Erbs, A. Elsässer et al., "Improved clinical outcome after intracoronary administration of bone-marrowderived progenitor cells in acute myocardial infarction: final 1year results of the REPAIR-AMI trial," European Heart Journal, vol. 27, no. 23, pp. 2775-2783, 2006.

[170] A. Rosenzweig, "Cardiac cell therapy-mixed results from mixed cells," The New England Journal of Medicine, vol. 355, no. 12, pp. 1274-1277, 2006.

[171] T. Umemura and Y. Higashi, "Endothelial progenitor cells: therapeutic target for cardiovascular diseases," Journal of Pharmacological Sciences, vol. 108, no. 1, pp. 1-6, 2008.

[172] C. Beauséjour, "Bone marrow-derived cells: the influence of aging and cellular senescence," Handbook of Experimental Pharmacology, vol. 180, pp. 67-88, 2007.

[173] O. M. Tepper, R. D. Galiano, J. M. Capla et al., "Human endothelial progenitor cells from type II diabetics exhibit impaired proliferation, adhesion, and incorporation into vascular structures," Circulation, vol. 106, no. 22, pp. 2781-2786, 2002.

[174] C. J. M. Loomans, E. J. P. De Koning, F. J. T. Staal et al., "Endothelial progenitor cell dysfunction: a novel concept in the pathogenesis of vascular complications of type 1 diabetes," Diabetes, vol. 53, no. 1, pp. 195-199, 2004.

[175] G. Lamirault, S. Susen, V. Forest et al., "Difference in mobilization of progenitor cells after myocardial infarction in smoking versus non-smoking patients: insights from the BONAMI trial," Stem Cell Research and Therapy, vol. 4, no. 6, article no. 152, 2013.

[176] B.-E. Strauer and G. Steinhoff, "10 Years of intracoronary and intramyocardial bone marrow stem cell therapy of the heart: from the methodological origin to clinical practice," Journal of the American College of Cardiology, vol. 58, no. 11, pp. 1095-1104, 2011.

[177] M. Gnecchi, Z. Zhang, A. Ni, and V. J. Dzau, "Paracrine mechanisms in adult stem cell signaling and therapy," Circulation Research, vol. 103, no. 11, pp. 1204-1219, 2008.

[178] C. E. Murry, M. H. Soonpaa, H. Reinecke et al., "Haematopoietic stem cells do not transdifferentiate into cardiac myocytes in myocardial infarcts," Nature, vol. 428, no. 6983, pp. 664-668, 2004.

[179] M. Gnecchi, H. He, O. D. Liang et al., "Paracrine action accounts for marked protection of ischemic heart by Akt-modified mesenchymal stem cells," Nature Medicine, vol. 11, no. 4, pp. 367-368, 2005.

[180] M.-M. Zaruba, M. Soonpaa, S. Reuter, and L. J. Field, "Cardiomyogenic potential of C-Kit+-expressing cells derived from neonatal and adult mouse hearts," Circulation, vol. 121, pp. 19922000, 2010.

[181] D. C. Andersen, P. Andersen, M. Schneider, H. B. Jensen, and S. P. Sheikh, "Murine 'cardiospheres' are not a source of stem cells with cardiomyogenic potential," STEM CELLS, vol. 27, no. 7, pp. 1571-1581, 2009.

[182] M. A. Laflamme and C. E. Murry, "Heart regeneration," Nature, vol. 473, no. 7347, pp. 326-335, 2011.

[183] R. Jackson, E. L. Tilokee, N. Latham et al., "paracrine engineering of human cardiac stem cells with insulin-like growth factor 1 enhances myocardial repair," Journal of the American Heart Association, vol. 4, no. 9, Article ID e002104, 2015. 
[184] S. Minatoguchi, G. Takemura, X.-H. Chen et al., "Acceleration of the healing process and myocardial regeneration may be important as a mechanism of improvement of cardiac function and remodeling by postinfarction granulocyte colony-stimulating factor treatment," Circulation, vol. 109, no. 21, pp. 2572-2580, 2004.

[185] S. Hamshere, S. Arnous, T. Choudhury et al., "Randomized trial of combination cytokine and adult autologous bone marrow progenitor cell administration in patients with nonischaemic dilated cardiomyopathy: the REGENERATEDCM clinical trial," European Heart Journal, vol. 36, no. 44, pp. 30613069, 2015.

[186] A. J. Boyle, R. Whitbourn, S. Schlicht et al., "Intra-coronary high-dose CD34+ stem cells in patients with chronic ischemic heart disease: a 12-month follow-up," International Journal of Cardiology, vol. 109, no. 1, pp. 21-27, 2006.

[187] A. T. Askari, S. Unzek, Z. B. Popovic et al., "Effect of stromalcell-derived factor 1 on stem-cell homing and tissue regeneration in ischaemic cardiomyopathy," The Lancet, vol. 362, no. 9385, pp. 697-703, 2003.

[188] G. Tan, W. Shim, Y. Gu et al., "Differential effect of myocardial matrix and integrins on cardiac differentiation of human mesenchymal stem cells," Differentiation, vol. 79, no. 4-5, pp. 260-271, 2010.

[189] A. Behfar, S. Yamada, R. Crespo-Diaz et al., "Guided cardiopoiesis enhances therapeutic benefit of bone marrow human mesenchymal stem cells in chronic myocardial infarction," Journal of the American College of Cardiology, vol. 56, no. 9, pp. 721-734, 2010. 


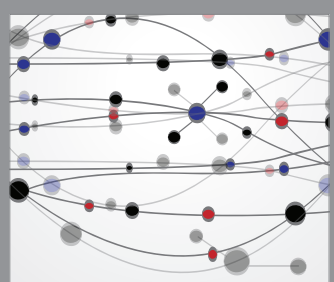

The Scientific World Journal
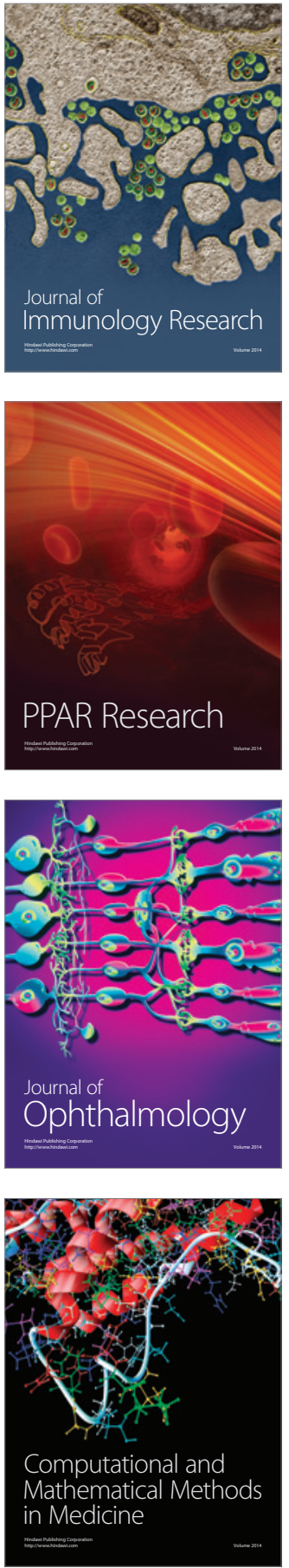

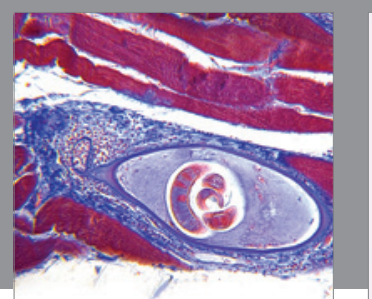

Gastroenterology Research and Practice
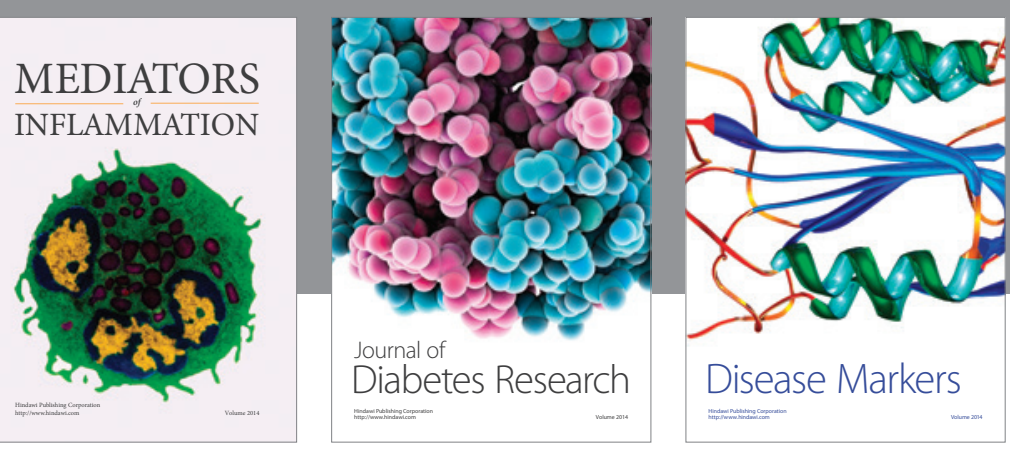

Disease Markers

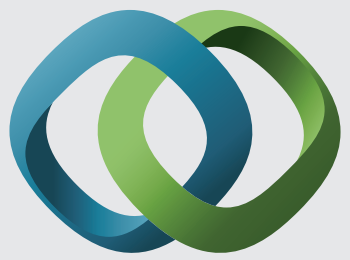

\section{Hindawi}

Submit your manuscripts at

https://www.hindawi.com
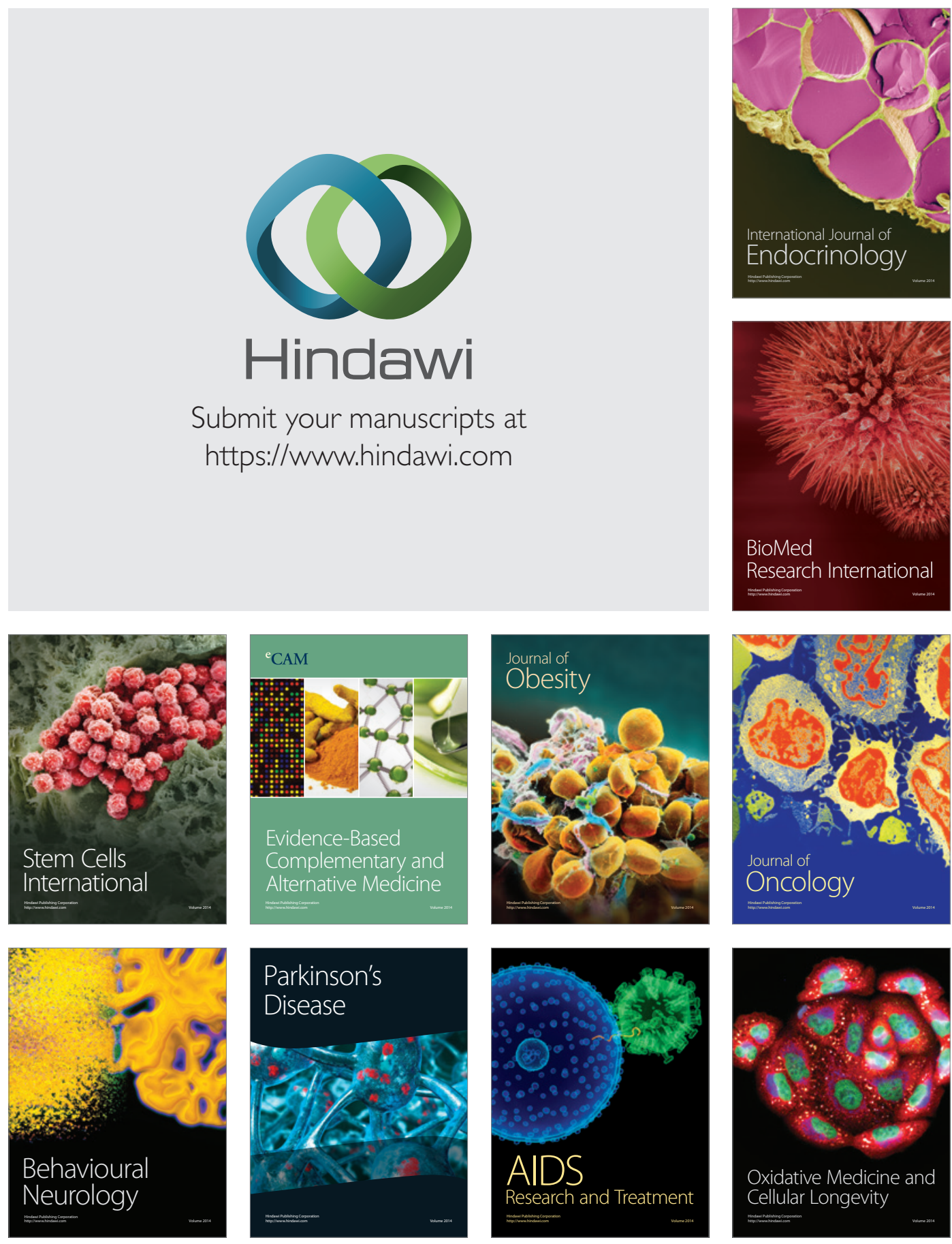